\title{
GEOHYDROLOGY AND DIGITAL-SIMULATION MODEL OF THE FARRINGTON AQUIFER IN THE NORTHERN COASTAL PLAIN OF NEW JERSEY
}

By George M. Farlekas

\section{U.S. GEOLOGICAL SURVEY}

Water-Resources Investigations $79-106$

Prepared in cooperation with

New Jersey Department of Environmental

Protection, Division of Water Resources

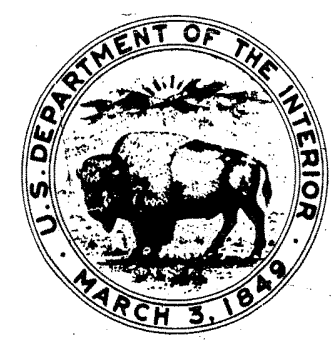




\section{UNITED STATES DEPARTMENT OF THE INTERIOR}

Cecil D. Andrus, Secretary

GEOLOGICAL SURVEY

H. William Menard, Director

For additional information write to:

U.S. Geological Survey Room 436, Federal Bldg.

P. O. Box 1238

Trenton, N. J. 08607 
Page

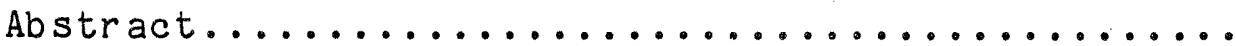

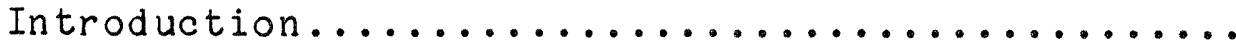

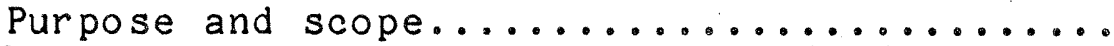

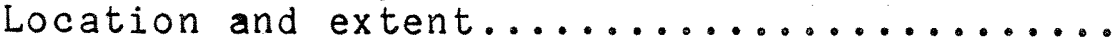

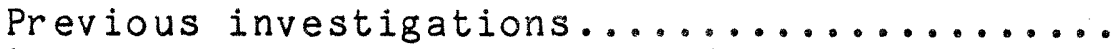

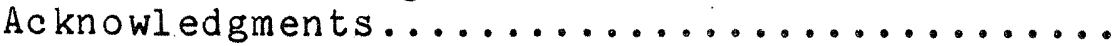

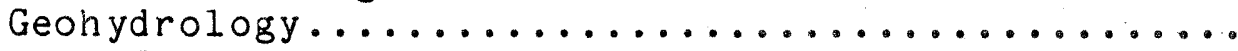

Potomac-Raritan-Magothy aquifer system.......

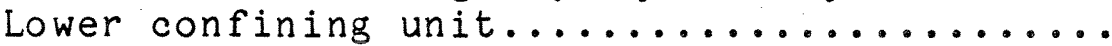

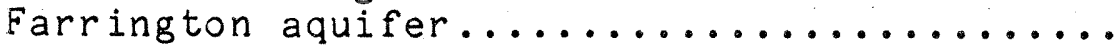

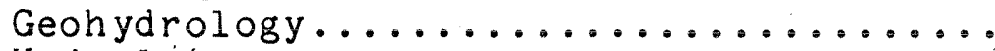

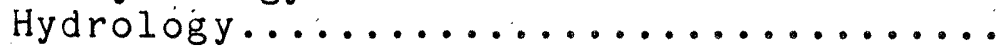

Hydraulic characteristics.........

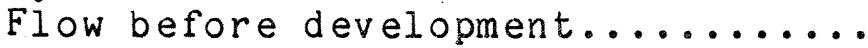

Potentiometric surfaces for 1959

and $1973 \ldots \ldots \ldots \ldots \ldots \ldots \ldots$

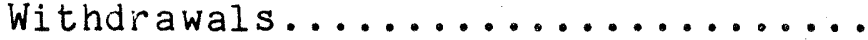

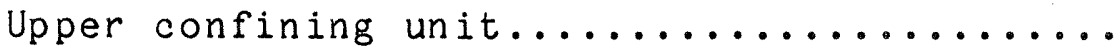

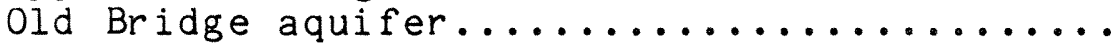

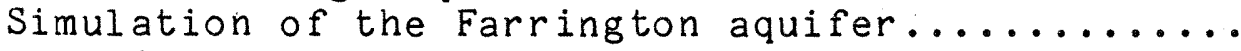

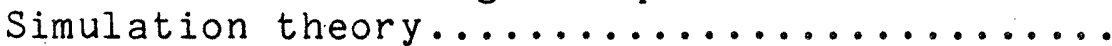

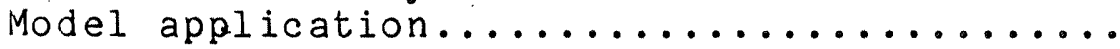

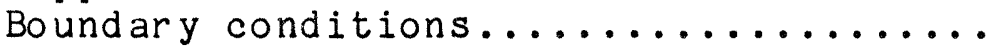

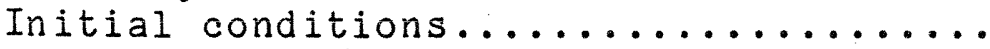

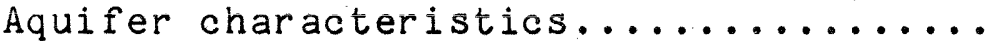

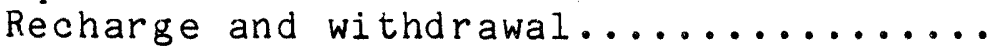

Confining unit characteristics.........

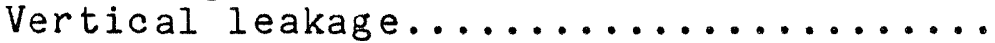

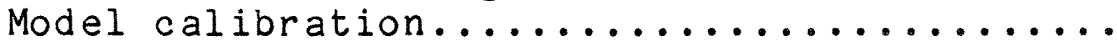

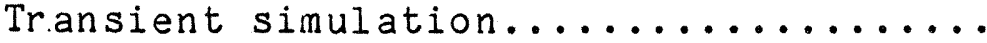

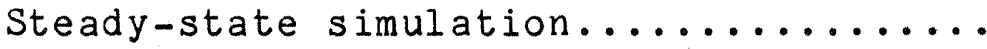

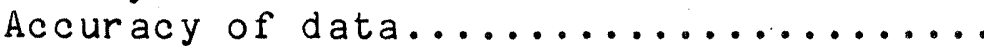

Potentiometric surfaces simulated due to

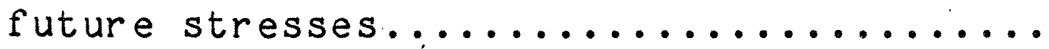

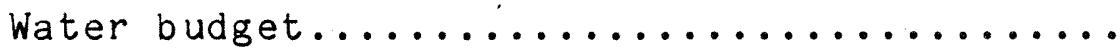

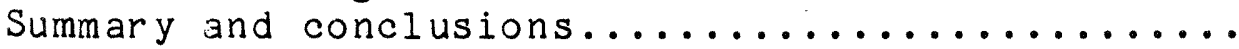

Selected references. 
Page

Figure 1. Map showing area of investigation....... 4

2. Structure contour of the top of the

Farrington aquifer................ 10

3. Thickness of the Farrington aquifer..... 11

4. Distribution of screen lengths, specific capacity, and specific capacity per foot of screen for large diameter wells tapping the Farrington aquifer.

5. Generalized potentiometric surface of the Farrington aquifer, 1959........ 15

6. Potentiometric surface of the Farrington aquifer, November $1973 \ldots . .17$

7. Actual and projected withdrawals from the Farrington aquifer, 1929-2000.... 18

8. Withdrawals from the Farrington aquifer,

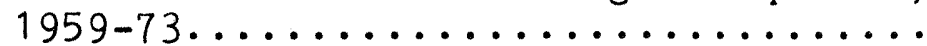

9. Thickness of the upper confining unit...

10. Generalized potentiometric surface of the Old Bridge aquifer, 1959........

11. Potentiometric surface of the Old Bridge

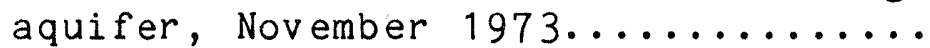

12. Index map of New Jersey showing variable rectangular grid used for the

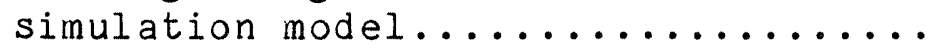

73. Transmissivity of the Farrington aquifer used in the simulation moc $1 \ldots . . .$.

14. Distribution of withdrawals from the Farrington aquifer, 1959 and $1973 \ldots$

15. Measured (November 1973) and simulated (year end 1973) potentiometric surface of the Farrington aquifer....

16. Cross section of the measured potentiometric surface, 1959 and November 1973, and simulated potentiometric surface for year end 1973,1985 , and $2000 \ldots \ldots \ldots \ldots \ldots \ldots$

17. Hydrographs of observed and simulated water levels in selected wells,

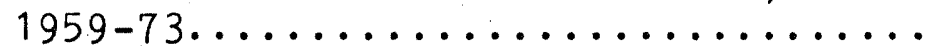

18. Simulated prepumping (1900) potentiometric surface of the Farrington

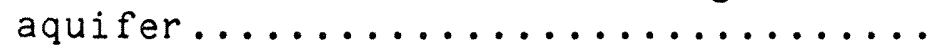

19. Distribution of estimated withdrawals from the Farrington aquifer, 1985

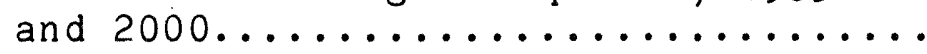

20. Simulated potentiometric surface of the Farrington aquifer, $1985 \ldots \ldots \ldots \ldots$.

21. Simulated potentiometric surface of the

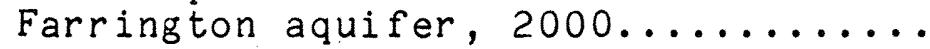

22. Decline of the simulated potentiometric 
surface of the Farrington aquifer,

$1973-85 \ldots \ldots \ldots \ldots \ldots \ldots \ldots \ldots . \ldots \ldots$

23. Decline of the simulated potentiometric

surface of the Farrington aquifer,

$1973-2000 \ldots \ldots \ldots \ldots \ldots \ldots \ldots \ldots \ldots$

\section{TABLE}

Table 1. Correlation of stratigraphic units in Middlesex and Monmouth Counties, New Jersey and Long Island, New

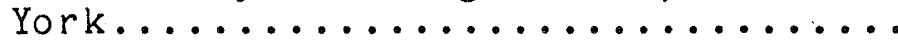


Factors for converting inch-pound units to metric are shown to four significant figures. However, in the text the metric equivalents are shown only to the number of significant figures consistent with the values for the inch-pound units.

\section{Inch-pound}

foot $(f t)$

foot per second (ft/s)

foot per day (ft/s)

square foot per day $\left(f^{2} / d\right)$

cubic foot per second $\left(\mathrm{ft}^{3} / \mathrm{s}\right)$

cubic foot per second per

square mile $\left[\left(\mathrm{ft}^{3} / \mathrm{s}\right) / \mathrm{mi}^{2}\right]$

million gallons per day

( $\mathrm{Mgal} / \mathrm{d}$ )

gallon per minute per foot

$[(\mathrm{gal} / \mathrm{min}) / \mathrm{ft}]$

gallon per minute per foot per foot $\left[(\mathrm{gal} / \mathrm{min}) / \mathrm{ft}^{2}\right]$

inch (in)

mile ( $\mathrm{mi}$ )

square mile $\left(m i^{2}\right)$
0.207

0.6791

2.540

1.609

Multiply by

0.3048

0.3048

0.3048

0.0929

0.02832

0.01093

0.01081

2.590
Metric

meter ( $m$ )

meter per second $(\mathrm{m} / \mathrm{s})$

meter per day $(\mathrm{m} / \mathrm{d})$

square meter per day $\left(\mathrm{m}^{2} / \mathrm{d}\right)$

cubic meter per second $\left(\mathrm{m}^{3} / \mathrm{s}\right)$

cubic meter per second per square kilometer $\left[\left(\mathrm{m}^{3} / \mathrm{s}\right) / \mathrm{km}^{2}\right]$

cubic meter per second $\left(\mathrm{m}^{3} / \mathrm{s}\right)$

liter per second per meter $[(\mathrm{L} / \mathrm{s}) / \mathrm{m}]$

liter per second per meter per meter $\left[(\mathrm{L} / \mathrm{s}) / \mathrm{m}^{2}\right]$

centimeter $(\mathrm{cm})$

kilometer $(\mathrm{km})$

square kilometer $\left(\mathrm{km}^{2}\right)$ 
A two-dinensional digital-computer flow model was developed to simulate the Farrington aquifer in the northern part of the Coastal Plain of New Jersey. The area of detailed study includes approximately 500 square miles in Middlesex and Monmouth Counties where the aquifer provides a large part of the municipal and industrial water supply. The area modeled is much larger, extending seaward as well as northeastward into Long Island.

The aquifer consists chiefly of the Farrington Sand Member of the Raritan Formation and is composed of sand and some gravel. It thickens from a featheredge in outcrop to more than 170 feet, 11 miles to the southeast. The confining unit between the Farrington and the overlying Old Bridge Sand Member of the Magothy Formation consists primarily of the Woodbridge Clay Member of the Raritan Formation and has a maximum thickness of 244 feet.

The model simulates both water-table and artesian conditions. The confining unit overlying the Farrington aquifer is simulated as having a variable thickness and vertical hydraulic conductivity. The effect of a declining water level in the overlying old Bridge aquifer on the Farrington aquifer is also simulated by the model.

Values used to describe the hydraulic properties of the Farrington aquifer are: a hydraulic conductivity of 105 feet per day, a storage coefficient of $1.6 \times 10^{-4}$ for artesian conditions, and a specific yield of 0.25 for water-table conditions. Values for the overlying confining unit are: a vertical hydraulic conductivity ranging from $4.2 \times 10^{-}$, to $1.0 \times 10^{-10}$ feet per second and a specific storage of $4 \times 10^{-5}$ feet $^{-1}$.

Aquifer simulation for the 15-year period, 1959-73, was used to calibrate the model. The model was calibrated by comparing the observed potentiometric surface of November 1973 with the simulated potentiometric surface. In addition, hydrographs for selected wells were compared with model results. Ground-water withdrawals for 1959 and 1973 were 12.1 and 28.5 million gallons per day, respectively.

Potentiometric surfaces for 1985 and 2000 were computed based on a linear projection of ground-water withdrawals $(39.5$ and 56.9 million gallons per day in 1985 and 2000 , respectively) of the period 1959 through 1973. These surfaces are deeper than that of November, 1973, and the cone of depression is wider. The potentiometric head projected by the model in the vicinity of Sayreville will be more than 150 feet below mean sea level by 2000; the head in this area was 70 feet below sea level in 1973 .

The model calculated ground-water budgets for steady-state and transient conditions for the entire modeled area and for several rectangular subareas. Ground-water flow into the modeled Farrington aquifer under steady-state conditions before 
ground-water development was 16 cubic feet per second for the entire area. Recharge in the outcrop area and vertical leakage from the old Bridge was 8 cubic feet per second each. Approximately 75 percent of the discharge occurred as seepage into surface-water bodies in and near the outcrop and as lateral flow southwestward into Burlington County near the outcrop area. The remaining 25 percent occurred southeast of the outcrop as vertical leakage into the overlying Old Bridge aquifer and as lateral flow to the south into Ocean and Burlington Counties.

A transient water budget for 1973 was calculated for a subarea consisting mainly of Middlesex County. The model indicates that 48 percent ( 14.3 cubic feet per second) of the total inflow to the subarea was through its boundaries. Other sources of water include direct recharge within the subarea ( 5.4 cubic feet per second), vertical leakage (mainly from the old Bridge) within the subarea ( 2.6 cubic feet per second), and water released from storage ( 3.4 cubic feet per second). Discharge from the subarea consisted mainly of withdrawals $(26.5$ cubic feet per second). It also included vertical leakage to the Old $\mathrm{Bridge}$ and discharge to surface-water bodies simulated by constant-head nodes ( 3.2 cubic feet per second). 
Purpose and Scope

The purpose of this study is to simulate the hydrology of the Farrington aquifer using a computer-simulation model so that the effects of alternative withdrawal schemes can be evaluated quantitatively. The primary study area consists of the northern part of the New Jersey Coastal Plain. The area modeled is much larger, extending seaward and also to the northeast into Long Island. This report discusses the geohydrology of the Farrington aquifer, the simulation model, and the effects of projected withdrawals from the Farrington aquifer. Saltwater intrusion, one of the limiting factors of future development of the aquifer, had not been investigated during this study. This study by the U.S. Geological Survey was done in cooperation with the Division of Water Resources of the New Jersey Department of Environmental Protection.

\section{Location and Extent}

The primary area of study consists of approximately $500 \mathrm{mi}^{2}$, including parts of Middlesex, Monmouth, and Mercer Counties (fig. 1). The modeled area is much larger, incorporating additional areas of New York and New Jersey. To the northeast, the model extends into Long Island. The southeastern boundary of the model is approximately $60 \mathrm{mi}$ offshore. The southwestern boundary extends to the southwestern limit of Monmouth County. The total area simulated by the model is approximately $7,500 \mathrm{mi}^{2}$.

\section{Previous Investigations}

The geology and ground-water resources of the Farrington aquifer in the northern part of the Coastal Plain of New Jersey have been studied for many years. Barksdale (1937) discussed the geology and hydrology of the Farrington Sand in Middlesex County. Barksdale and others (1943) completed an investigation of the ground-water resources of Middlesex County, with special emphasis on the coastal plain. Appel (1962) reported on saltwater encroachment into the Farrington and Old Bridge aquifers in the Sayreville area, Middlesex County. Hasan, Kasabach, and Malone (1969) discussed the Old Bridge aquifer in the Sayreville area of Middlesex County. Reports on the ground-water resources of several counties in the northern part of the New Jersey Coastal Plain include: Jablonski (1968) on Monmouth County, Anderson and Appel (1969) on Ocean County, and Vecchioli and Palmer (1962) and Widmer (1965) on Mercer County. Wilson and others (1972) reported on the water resources of the Upper Millstone River basin, with emphasis on the water-table aquifer. The Potomac-Raritan-Magothy aquifer system in the New Jersey Coastal Plain was described by Gill and Farlekas (1976). 


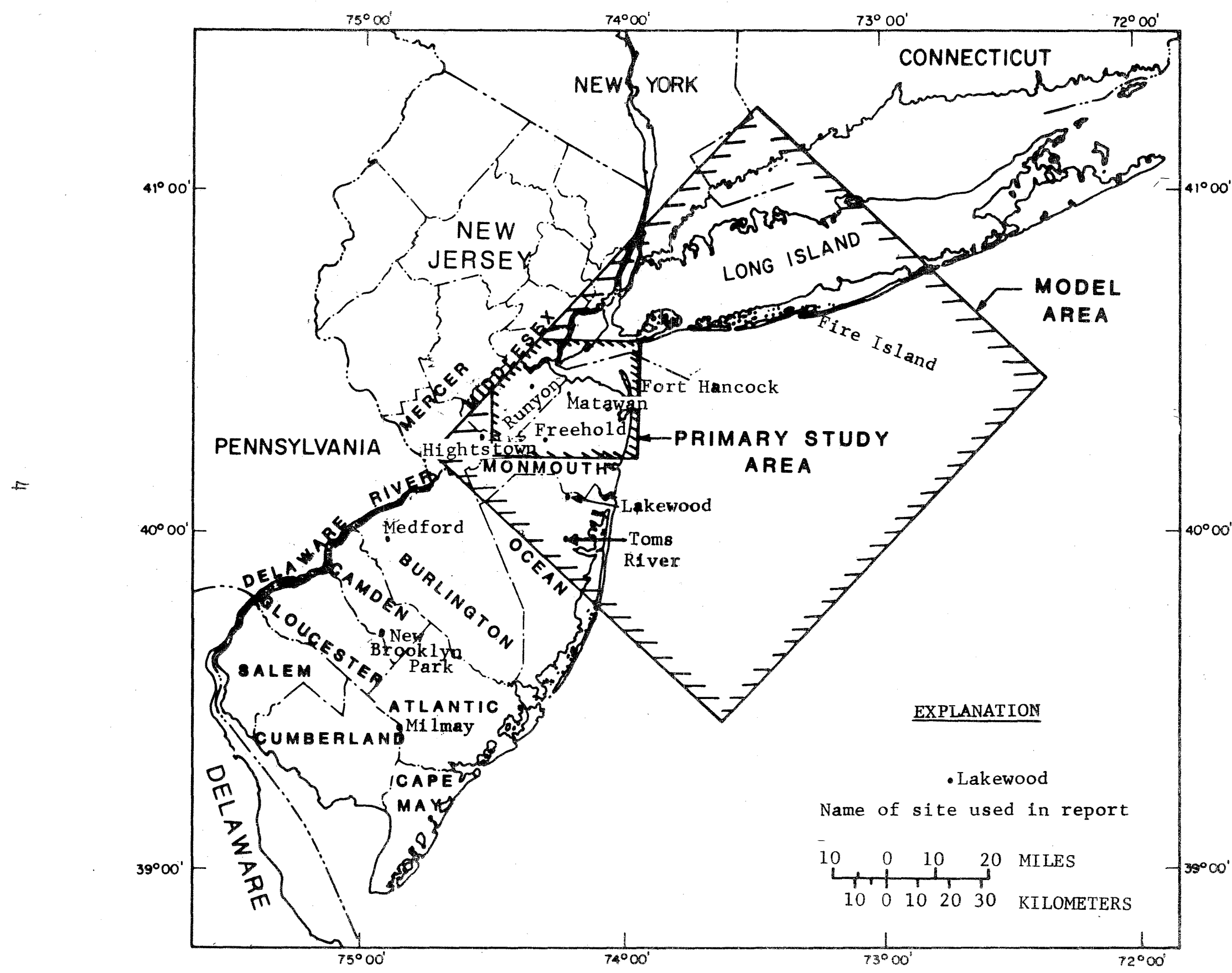

Figure 1.--Map showing area of investigation. 
Recent investigations of the geology of the northern part of the Coastal Plain of New Jersey include a report by Owens, Minard, and Sohl (1968) on the Cretaceous deltas and a report by Owens and Sohl (1969) on the Cretaceous-Tertiary shelf and deltaic paleoenvironments. A recent paper by Perry and others (1975) presents a survey of the stratigraphy of the Atlantic Coastal Margin and includes detailed stratigraphic sections of the northern part of the New Jersey Coastal Plain.

\section{Acknowledgments}

The assistance of state government officials and private individuals is gratefully acknowledged for furnishing well information and permitting access to wells. Special thanks are extended to the Duhernal water System officials for providing hydrologic data from their files. Gerard P. Lennon and Flavian Stellerine, both formerly of the U.S. Geological Survey, provided valuable assistance with computer programming.

\section{GEOHYDROLOGY}

\section{Potomac-Raritan-Magothy Aquifer System}

The northern part of the Atlantic Coastal Plain of New Jersey is underlain by unconsolidated silt, clay, sand, and gravel deposited under fluvial, fluvial-deltaic, and marine conditions. The sediments range in age from Early Cretaceous to Holocene and lie unconformably on a pre-Cretaceous bedrock consisting mainly of sedimentary and igneous rocks of Triassic age and older crystalline rocks. The unconsolidated sediments crop out in northeast-southwest directions and thicken downdip to the southeast. Their thickness ranges from a featheredge in Middlesex County to about $1,700 \mathrm{ft}$ in Monmouth County (Gill and Farlekas, 1976). The present study is concerned with the lower part of this sedimentary sequence.

The most productive source of ground water in the northern part of the New Jersey Coastal Plain is the Potomac-RaritanMagothy aquifer system, which is made up of the Potomac Group and the Raritar and Magothy Formations of Cretaceous age. This wedge-shaped aquifer system, consisting of quartz sand with some gravel, silt, and clay, thickens from a featheredge at its outcrop in Middlesex County to a maximum of about $600 \mathrm{ft}$ in Monmouth County (Gill and Farlekas, 1976). Overlying the Potomac-RaritanMagothy aquifer system is a confining unit consisting of the Cretaceous Merchantville Formation and the Woodbury Clay. It is the most extensive confining unit in the New Jersey Coastal Plain and ranges in thickness from a featheredge in Middlesex County to a maximum of approximately $300 \mathrm{ft}$ in Monmouth County. Structure contour maps of the top of the Merchantville Formation, the Magothy Formation, and the pre-Cretaceous bedrock in New Jersey appear in Gill and Farlekas (1976). 
The Potomac-Raritan-Magothy aquifer system in the northern part of the New Jersey Coastal Plain contains two major aquifers; the Farrington aquifer, consisting mainly of the Farrington Sand Member of the Raritan Formation, and the old Bridge aquifer, consisting mainly of the Old Bridge Sand Member of the Magothy Formation. The Old Bridge Sand Member was originally placed in the upper part of the Raritan Formation. However, Wolfe and Pakiser (1971, p. 41) designated the unit as the basal member of the younger Magothy Formation. An analysis of geophysical and water-level data indicate that the Farrington and the Old Bridge function as separate aquifers in Middlesex County, and each can be traced downdip into Monmouth County.

The Woodbridge Clay Member of the Raritan Formation, an extensive confining unit that separates the Farrington Sand Member from the overlying old Bridge Sand Member, can also be traced downdip from the outcrop area in Raritan Bay to the shore area in Monmouth County. This interpretation is supported by a recently published cross section along the Atlantic Coast (Perry and others, 1975, p. 1542). The stratigraphic section shown in Table 1 is modified from Perry and others (1975, p. 1539) and shows the correlation of part of the Cretaceous section in the northern part of the Coastal Plain of New Jersey (Middlesex and Monmouth Counties) with sediments on Long Island.

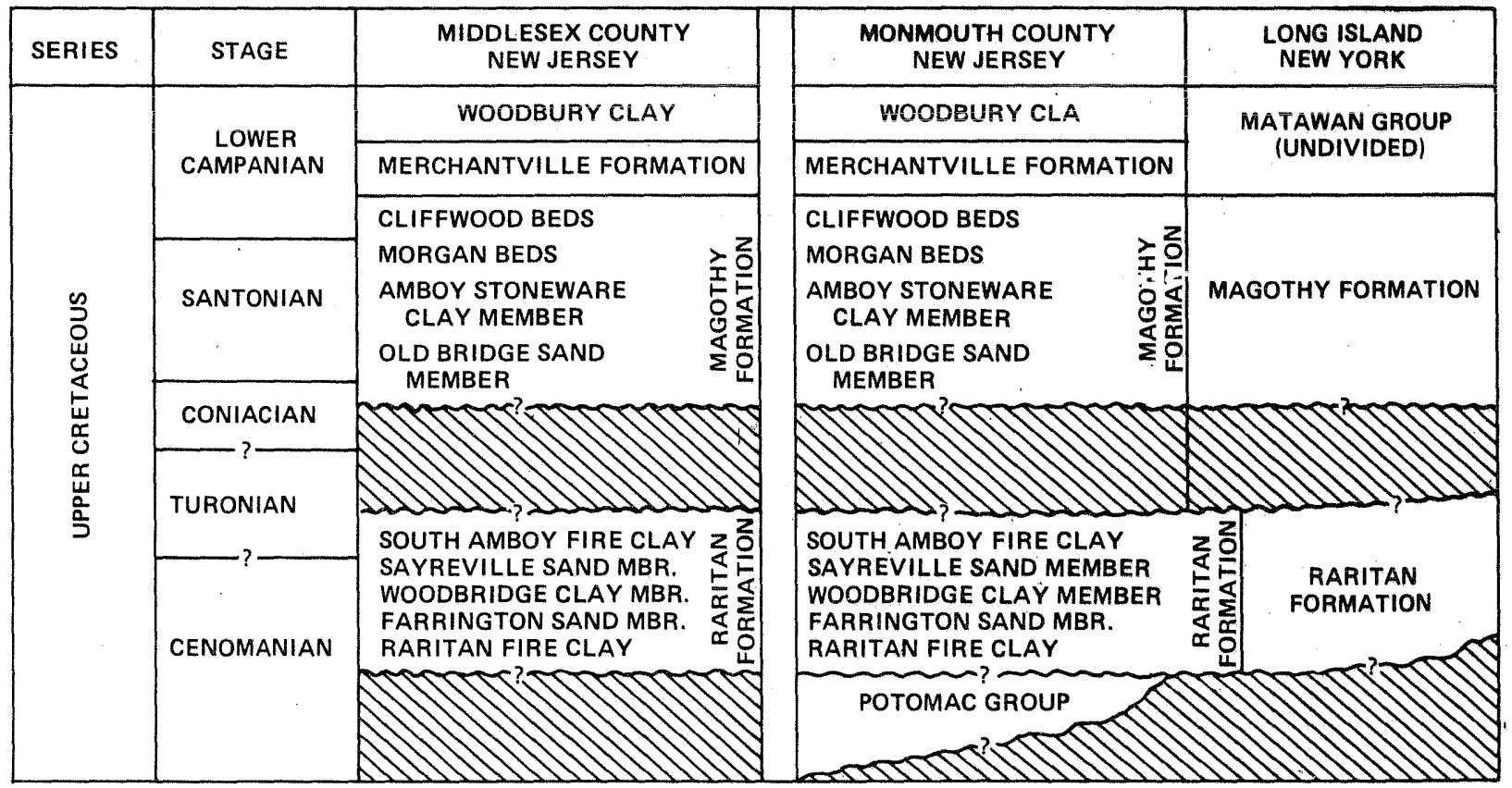

Table 1..-Correlation of stratigraphic units in Middlesex and Monmouth Counties, New Jersey and Long Island, New York (Modified from Perry and others, 1975). 


\section{Lower Confining Unit}

The lower confining unit in Middlesex County, as defined in this report, consists mainly of a layer of clay and the underlying consolidated rocks. Southeast of the Monmouth-Middlesex County line, the lower confining unit is defined as the first layer of clay thicker than $20 \mathrm{ft}$ beneath the Farrington aquifer.

In Middlesex County, the upper part of the lower confining unit is the Raritan fire clay (Barksdale and others, 1943). This clay lies between the Farrington Sand Member and bedrock in much of Middlesex County. Near the Farrington outcrop, the Raritan fire clay ranges in thickness from 0 to $35 \mathrm{ft}$, and the thickness increases downdip (Barksdale and others, 1943, p. 140). Well data near Spotswood, Old Bridge, Runyon, Parlin, and South Amboy indicate a thickness of up to $86 \mathrm{ft}$ for the Raritan fire clay.

The lower part of the confining unit in Middlesex County consists of rocks of Triassic age and pre-Triassic crystalline rocks. An analysis of drillers' logs indicates that Triassic rocks extend beneath the northwestern edge of the coastal plain southward for approximately $5 \mathrm{mi}$. Farther southeast, the bedrock is composed of pre-Triassic crystalline rocks. The thickness of the Triassic and crystalline rocks is not known.

Within the Triassic sequence is a thick diabase sill, which is exposed north of the study area along the Hudson River, where it forms the Palisades. The same diabase sill occurs on Staten Island, N.Y., in Middlesex County, N.J., and farther west. The sill is a continuous unit within the study area and is overlain by post-Triassic sediments (Barksdale and others, 1.943, p. 15). The hydrologic significance of this sill will be discussed in the section on aquifer characteristics.

The lower confining unit southeast of the Middlesex-Monmouth County line is defined as the first confining layer of clay below the Farrington aquifer thicker than $20 \mathrm{ft}$. Only a few wells or test holes completely penetrate the Farrington in this area. Consequently, data on the sediments between the Farrington and bedrock are scant. Geophysical logs of a test hole just north of Freehold Borough suggest the presence of at least $60 \mathrm{ft}$ of silt and clay below the principal aquifer. Southeast of the MiddlesexMonmouth County line, geophysical logs indicate a thickness of up to $200 \mathrm{ft}$ for the lower confining unit. 


\section{Farrington Aquifer}

Geohydrology

The Farrington aquifer in the northern Coastal Plain of New Jersey consists primarily of the Farrington Sand Member of the Raritan Formation. At or near its outcrop, the aquifer includes the Farrington Sand Member and overlying sand and gravel beds. In Middlesex County southeast of the outcrop, the aquifer consists solely of the Farrington Sand Member. Southeast of the MiddlesexMonmouth County line, the aquifer, as defined in this report, consists of the Farrington Sand and the underlying uppermost sand layers of the Potomac Group, which are hydraulically connected to the Farrington.

In Middlesex County, the Farrington Sand Member has been described as coarse to fine sand with lignite and pyrite. Locally, it contains clay beds (Barksdale and others, 1943, p. 104-105). In Middlesex County, its thickness ranges from 0 to 129 ft. Near South River, Sayreville, and Old Bridge the thickness of the Farrington ranges from 44 to $104 \mathrm{ft}$. It is either thin or missing above the Triassic diabase sill between the Borough of South River and Perth Amboy City due to erosion or a lack of deposition during Cretaceous time (Barksdale and others, 1943, p. 106). The sand was deposited in a subaerial deltaic environment near the outcrop area and in a marine environment downdip along the coast (Perry and others, 1975, p. 1543). North of the Raritan River, the northwesterly part of the Farrington Sand Member in Middlesex County is overlain by a unit consisting of sand and, in places, clayey sediments (Barksdale and others, 1943, p. 19 and p. 58). Farther north in Middlesex County, the northwesterly part of the Farrington is overlain by glacial deposits of considerable thickness (Barksdale, 1937, p. 6). Information on the Farrington at the New Jersey-New York State line beneath Arthur Kill is not available. On staten Island, the northwesterly part of the Farrington is overlain by glacial deposits consisting of ground moraine and terminal moraine and some glacial outwash (Perlmutter and Arrow, 1953, plate 2).

Near the Raritan River, the Farrington Sand Member is overlain by Pleistocene or Holocene deposits consisting of highly permeable sand and gravel. In some places, the overlying deposits are dense and nearly impermeable. In places, the ancestral Raritan River eroded through the Farrington, disrupting its continuity. The Farrington has been replaced with relatively impermeable river mud. This mud, where present, restricts the hydraulic connection between the part of the Farrington north of the Raritan River with the part south of the river (Barksdale, 1937$, p. $3-6)$.

Along the Washington Canal, the overlying confining unit (Woodbridge Clay Member), together with all or part of the Farrington Sand Member, has been eroded. Here, Holocene sand and 
gravel were deposited directly on the Farrington and the Triassic bedrock, thus increasing the thickness of the aquifer (Barksdale, $1937, \mathrm{p} .6-9)$.

South of the Raritan River, the northwesterly part of the Raritan and Magothy Formations are covered by surficial deposits of fine to very coarse sand and local basal beds of gravel (Owens and Minard, 1975). Near Hightstown, the surficial deposits reach a thickness of $94 \mathrm{ft}$. Where the surficial deposits are in direct contact with the underlying Farrington Sand Member, the thickness and effective recharge area of the Farrington is increased. Wilson and others $(1972, p .27)$ state that west of the New Jersey Turnpike in the Upper Millstone River basin, where the surficial deposits overlie Cretaceous sediments, the entire section acts essentially as a single water-table aquifer.

Southeast of the Middlesex-Monmouth County line, few wells penetrate the Farrington. Sand Member and, consequently, data are sparse. However, geophysical data at Lakewood, Freehold, Toms River, and Sandy Hook, and palynological analyses of cores from wells at Fort Dix, Matawan, Sandy Hook, and Toms River (Perry and others, 1975, p. 1542; Sirkin, written commun., 1971) indicate that the Farrington is separated from the underlying sands of the Potomac Group by a relatively thin confining unit. The unit may be equivalent to the Raritan fire clay. At Sandy Hook and Toms River, this confining unit is only 10 to $20 \mathrm{ft}$ thick (Perry and others, 1975, p. 1542). The thinness of this confining unit strongly suggests that the Farrington and some Potomac sands act as a single aquifer in Monmouth and Ocean Counties in the study area. For this reason, in the area southeast of the MiddlesexMonmouth County line, the Farrington aquifer, as defined in this report, includes the uppermost Potomac sand unit.

The top of the Farrington aquifer strikes in a northeastsouthwest direction and dips to the southeast 45 to $60 \mathrm{ft} / \mathrm{mi}$. A structure contour map of the top of the aquifer constructed primarily from geophysical logs is shown in figure 2. The altitude of the top of the aquifer near the Middlesex-Monmouth County line is approximately $400 \mathrm{ft}$ below mean sea level. Near Freehold, the tcp is approximately $700 \mathrm{ft}$ below mean sea level.

A thickness map of the Farrington aquifer, constructed from geophysical logs and geologists' and drillers' logs, is shown in figure 3. More than 50 geophysical logs were used, most of which were obtained from wells within $6 \mathrm{mi}$ of the outcrop area. The aquifer, is thickest, about $170 \mathrm{ft}$, in Marlboro Township, Monmouth County (fig. 3). 


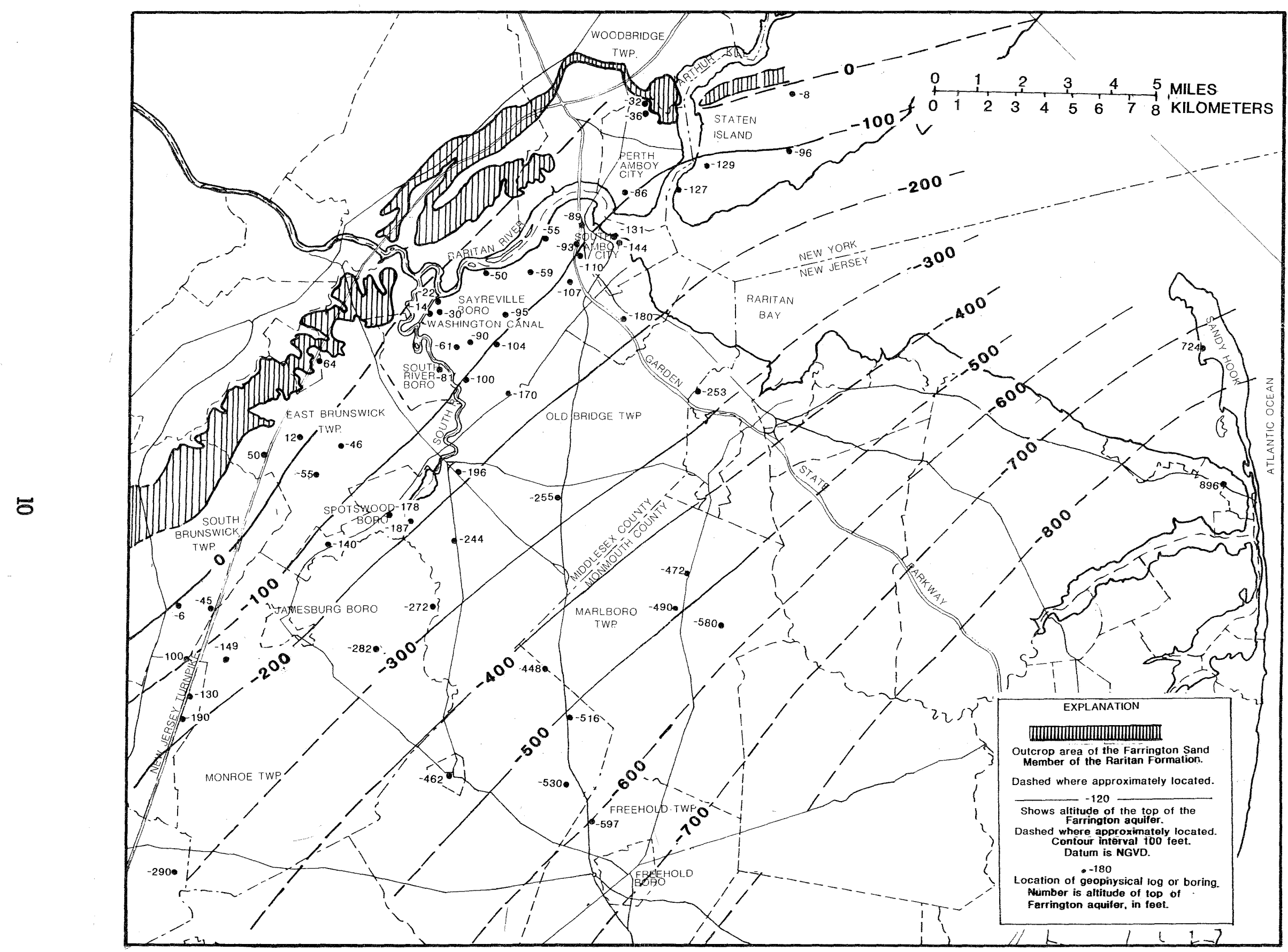

Figure 2--Structure contour of the top of the Farrington aquifer. 


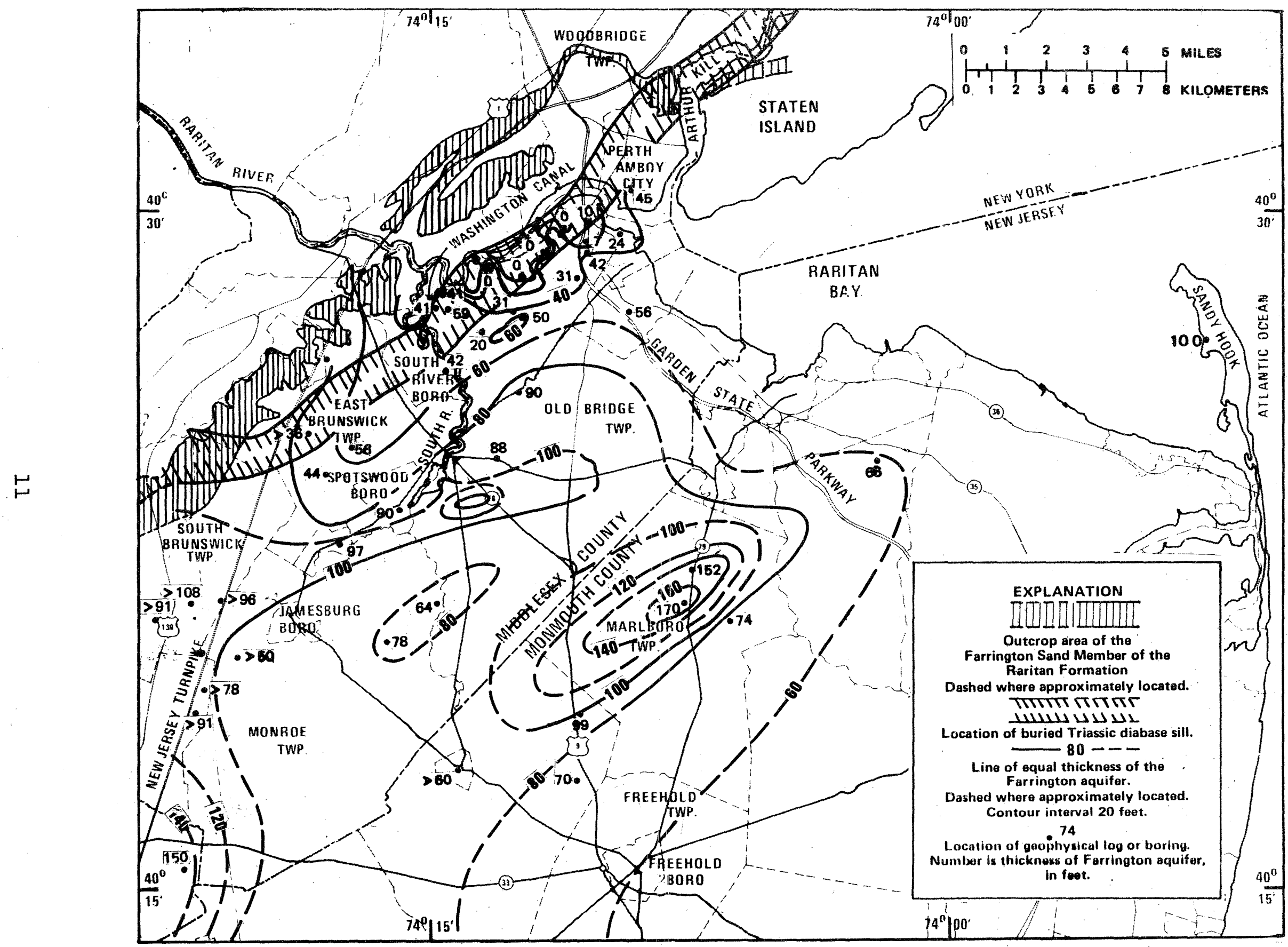

Figure 3.--Thickness of the Farrington aquifer. 
Hydrology

Hydraulic Characteristics

Only a few aquifer tests of the Farrington aquifer have been made. At the Perth Amboy Water Works in Old Bridge Township, hydraulic conductivity was reported to be 160 to $200 \mathrm{ft} / \mathrm{d}$ (Barksdale and others, 1943, p. 106). Near Woodbridge, Middlesex County, transmissivity was reported to be $2,145 \mathrm{ft}^{2} / \mathrm{d}$ and storage coefficient to be $2.3 \times 10^{-}$" (Hardt and Jablonski, 1959, p. 4). The thickness of the aquifer at this site determined from drillers' logs, is approximately $20 \mathrm{ft}$, indicating a hydraulic conductivity of $107 \mathrm{ft} / \mathrm{d}$.

In 1956, Leggette and others (1959) made an extensive 7-day aquifer test in South Brunswick Township $3.5 \mathrm{mi}$ west of Jamesburg. Five observation wells were used to measure drawdown caused by pumping $2.23 \mathrm{ft}^{3} / \mathrm{s}$. Pumping test data analyzed by Thiem's equation (Thiem, 1906) indicated a transmissivity of $14,740 \mathrm{ft}^{2} / \mathrm{d}$ and a storage coefficient of $1 \times 10^{-4}$. Their report states that the chief source of recharge to the Farrington aquifer during the test was vertical leakage from the overlying formations.

The 7-day aquifer test was analyzed during the present study. A digital-simulation model was constructed to reproduce field results of the aquifer test, and the pumping test data were analyzed by the Hantush modified method for leaky aquifers (Hantush, 1960). Results of these two analyses were in good agreement; an average transmissivity of $13,400 \mathrm{ft}^{2} / \mathrm{d}$ and a storage coefficient of $1.6 \times 10^{-}$were used. Based on a thickness of 62 ft, the hydraulic conductivity of the Farrington aquifer was calculated to be $216 \mathrm{ft} / \mathrm{d}$.

In addition, the simulation model and the Hantush method provided a value of $9.7 \times 10^{-7} \mathrm{ft} / \mathrm{s}$ for the vertical hydraulic conductivity of the overlying confining unit. The magnitude of this value suggests that considerable leakage through the confining unit at the site of the test could occur and supports Leggette and others' (1959) conclusions that vertical leakage was the chief source of recharge for the Farrington aquifer during the test.

Aquifer transmissivities can be estimated by using the specific capacity of a well. Specific capacity of a well is defined as the yield per unit decline of water level. A high specific capacity indicates that the aquifer is capable of yielding large quantities of water to wells and suggests that the aquifer has a high transmissivity. Specific capacities, as well as screen lengths, were compiled for 99 wells tapping the Farrington aquifer in the study area as an aid in determining hydraulic characteristics. Only wells with screen diameters of 8 inches or greater were considered. Data from well acceptance tests of 8 hours or more were used. Most of the 99 wells are in Middlesex County. The frequency distribution of specific capacity 
is shown in figure 4. The specific capacities range from 1.2 to 56.2 (gal/min)/ft of drawdown with a mean of 20.4 (gal/min)/ft of drawdown. The specific capacity of a well divided by the length of the well screen may be useful when comparing specific capacities of wells having different lengths. The screen lengths of the 99 wells range from 10 to $84 \mathrm{ft}$ (fig. 4). The distribution of values of specific capacity per foot of well screen for the 99 wells tapping the Farrington aquifer (fig. 4 ) ranges from 0.04 to 2.37 (gal/min)/ft per foot of well screen with an average of 0.62 (gal/min)/ft per foot of well screen. The method used to estimate transmissivity from specific capacity per foot of well screen is given in the section on Aquifer Characteristics.

\title{
Flow Before Development
}

Prior to the significant withdrawal of water from the Farrington aquifer, flow was from topographically high recharge areas in and near the outcrop in the vicinity of South Brunswick Township southeast toward Monmouth County and the New Jersey coast and south toward Mercer and Ocean Counties (Barksdale and others, 1958, p. 109-112; Gill and Farlekas, 1976). Isolated potentiometric highs associated with topographic highs occurred southeast of the outcrop area.

Recharge from precipitation occurs in the outcrop of the Farrington. Recharge, to the Farrington also takes place downdip from the outcrop as a result of vertical leakage from the old Bridge aquifer where the latter is under water-table conditions. The water table in the outcrop area of the Old Bridge is several feet higher than water levels in the Farrington aquifer.

Discharge from the Farrington aquifer prior to ground-water development was upward into the overlying aquifers in the area offshore from Monmouth and Ocean Counties, as well as to Arthur Kill, the Raritan River, and smaller streams in the outcrop area. Discharge of ground water also occurred southwestward into the outcrop area of the Potomac-Raritan-Magothy aquifer system along the Delaware River in Burlington County.

\section{Potentiometric Surfaces for 1959 and 1973}

\begin{abstract}
A map of the 1959 potentiometric surface of the Farrington aquifer was constructed utilizing water-level data from observation wells equipped with continuous recorders and from other water-level data collected from 1958 through 1960. Most of the data were for wells tapping the aquifer in Middlesex and Mercer Counties. The potentiometric map (fig. 5) shows a regional cone of depression centered in the Sayreville area with the lowest point approximately $20 \mathrm{ft}$ below mean sea level. The major recharge area in 1959 was located at or near the outcrop in South Brunswick Township. However, the hydraulic gradient in the area from the Washington Canal to Sayreville was reversed from its prepumping configuration. The Washington Canal area changed from
\end{abstract}



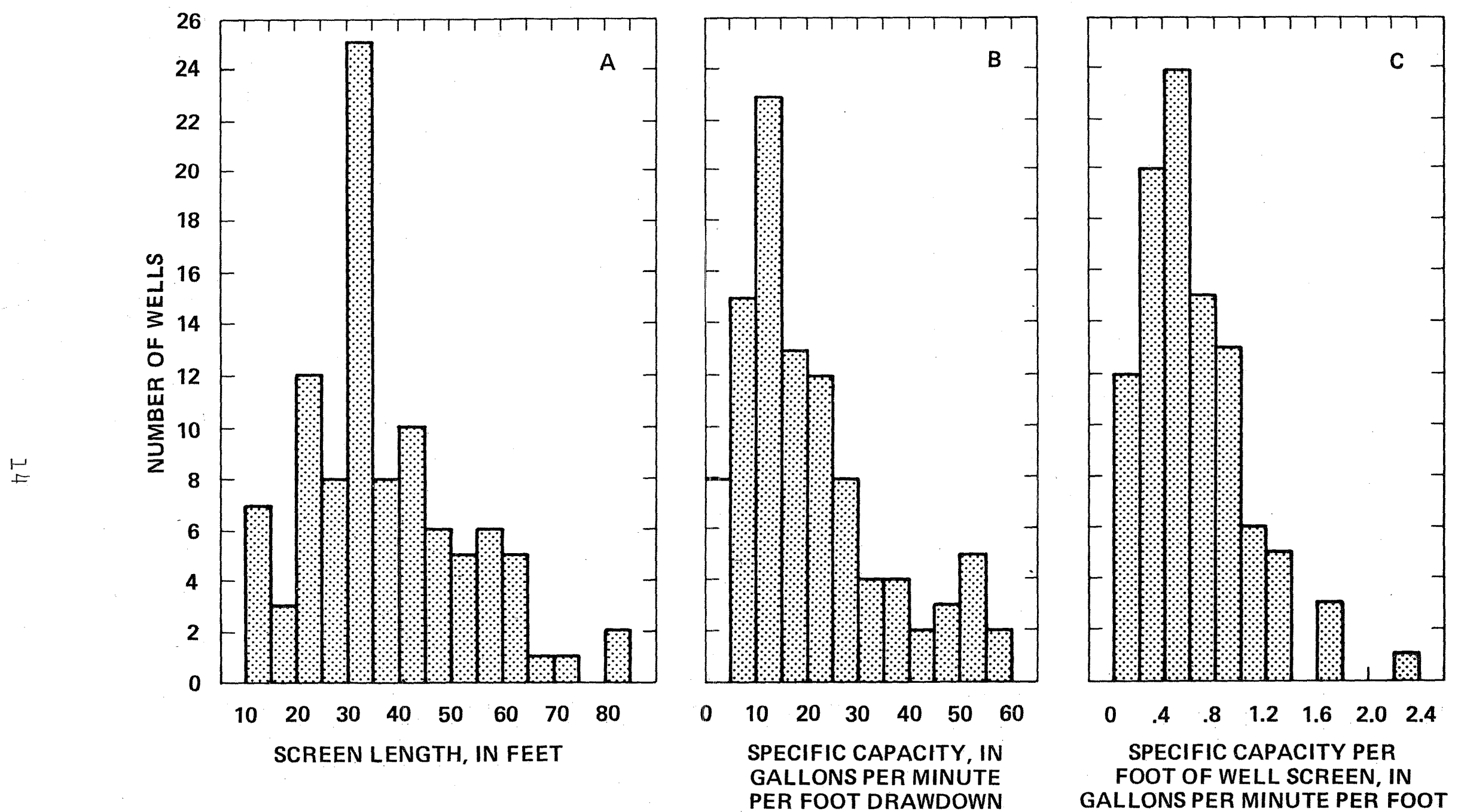

Figure 4.--Distribution of screen lengths, specific capacity, and specific capacity per foot of screen for large diameter wells tapping the Farrington aquifer. 


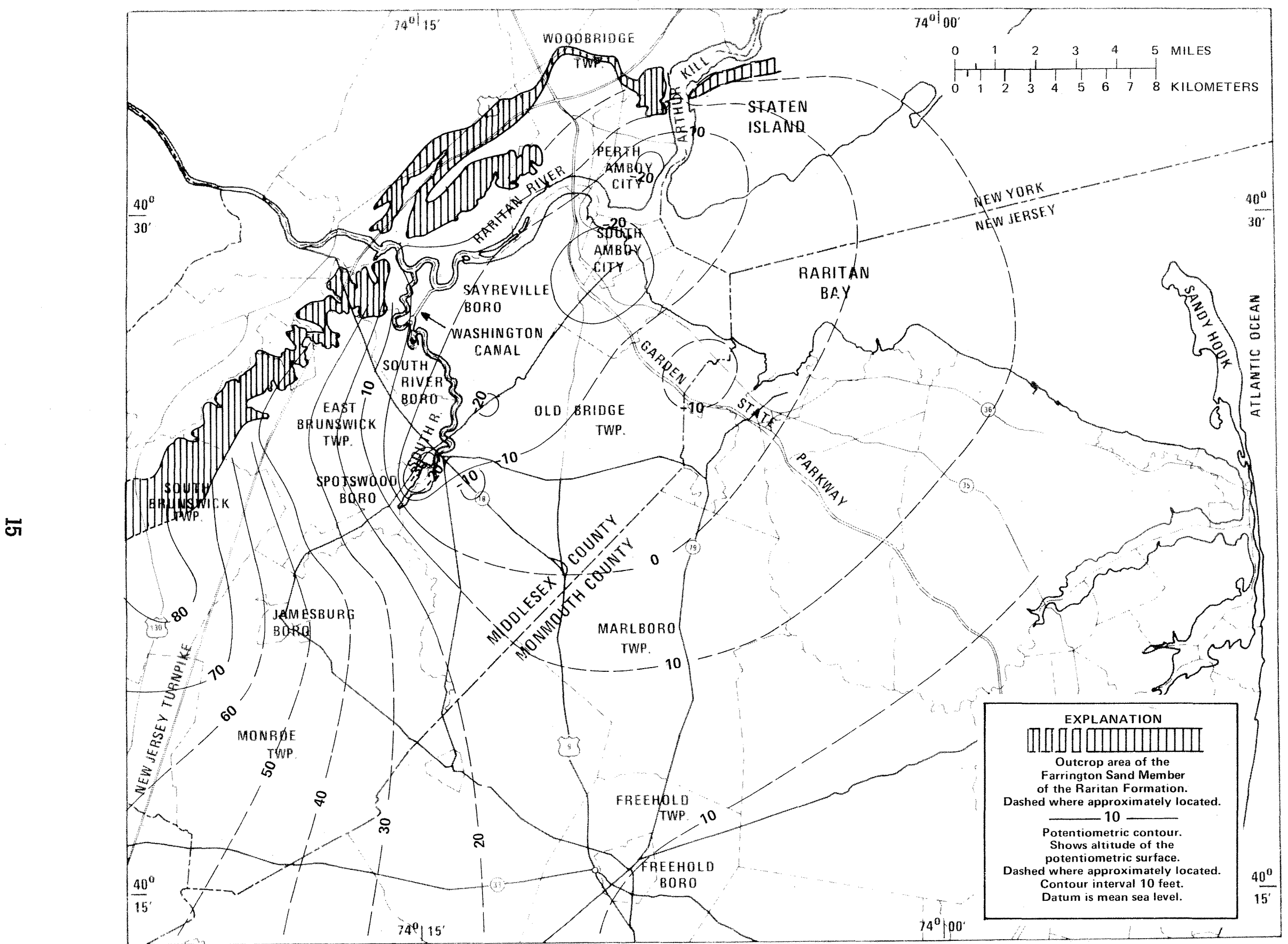

Figure 5. Generalized potentiometric surface of the Farrington aquifer, 1959. 
a discharge to a recharge area prior to 1959. Ground-water flow in 1959 was from the canal to Perth Amboy's Runyon well field (fig. 5).

Water-level measurements made in November 1973 at more than 180 wells were used to construct a 1973 potentiometric surface for the Farrington aquifer. The map (fig. 6) shows a deeper and more extensive cone of depression with the lowest point in excess of 70 ft below mean sea level in the Sayreville area. The gradient from the Washington Canal to Perth Amboy's Runyon well field increased $10 \mathrm{ft} / \mathrm{mi}$ between 1959 and November 1973. Water levels in the major recharge area of South Brunswick Township area did not change significantly from 1959 to November 1973.

\section{Withdrawals}

Withdrawals from the Farrington aquifer south of the Raritan River began at Perth Amboy's Runyon well field in 1897. By 1914 total withdrawals from the Farrington aquifer in Middlesex County "did not exceed one or two million gallons daily" (Barksdale and others, 1943, p. 107). Annual withdrawal data presented by Barksdale and others (1943, p. 108) for the period 1929-42 are shown in figure 7 together with withdrawals for the period 1959-73. The peak withdrawal of $12 \mathrm{Mgal} / \mathrm{d}\left(18 \mathrm{ft}^{3} / \mathrm{s}\right)$ for the period of 1929-42 occurred in 1936. The lowest withdrawal rate of $7 \mathrm{Mgal} / \mathrm{d}\left(11 \mathrm{ft}^{3} / \mathrm{s}\right)$ for the period occurred in 1942.

Ground-water withdrawals from the Farrington aquifer for the period 1959-73 are presented in figure 8. The total withdrawal shown includes irrigation, public supply, and industrial use. Irrigation withdrawals did not exceed $0.3 \mathrm{Mgal} / \mathrm{d}\left(0.5 \mathrm{ft}^{3} / \mathrm{s}\right)$ and, therefore, are not shown in figure 8. Total withdrawal increased 113 percent, from $12.1 \mathrm{Mgal} / \mathrm{d}\left(18.7 \mathrm{ft}^{3} / \mathrm{s}\right)$ in 1959 to $25.8 \mathrm{Mgal} / \mathrm{d}$ $\left(1.4 \mathrm{ft}^{3} / \mathrm{s}\right)$ in 1973. Public supply and industrial withdrawals during the period 1959-65 were approximately equal and each increased at an average annual rate of $0.2 \mathrm{Mgal} / \mathrm{d}(0.3 \mathrm{ft} / \mathrm{s})$. However, during the period 1966-73, yearly industrial withdrawals were virtually unchanged; while, public-supply withdrawals

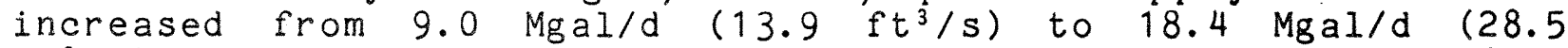
$\left.\mathrm{ft}^{3} / \mathrm{s}\right)$, an average annual rate of increase of $1.2 \mathrm{Mgal} / \mathrm{d}$ (1.9 $\left.\mathrm{ft}^{3} / \mathrm{s}\right)$. Much of the increase in public-supply withdrawals from 1966 to 1973 occurred southeast of the Old Bridge-Sayreville area.

\section{Upper Confining Unit}

The upper confining unit for the Farrington aquifer as defined in this report consists mainly of the Woodbridge Clay Member of the Raritan Formation. The upper confining unit also includes the clayey segment of the overlying Sayreville Sand Member and the South Amboy Fire Clay Member, both of the Raritan Formation, when these units are in direct contact with the Woodbridge. This confining unit is quite extensive and has been traced into Monmouth County on the basis of geophysical logs and palynological data. A thickness map of the confining unit, based 


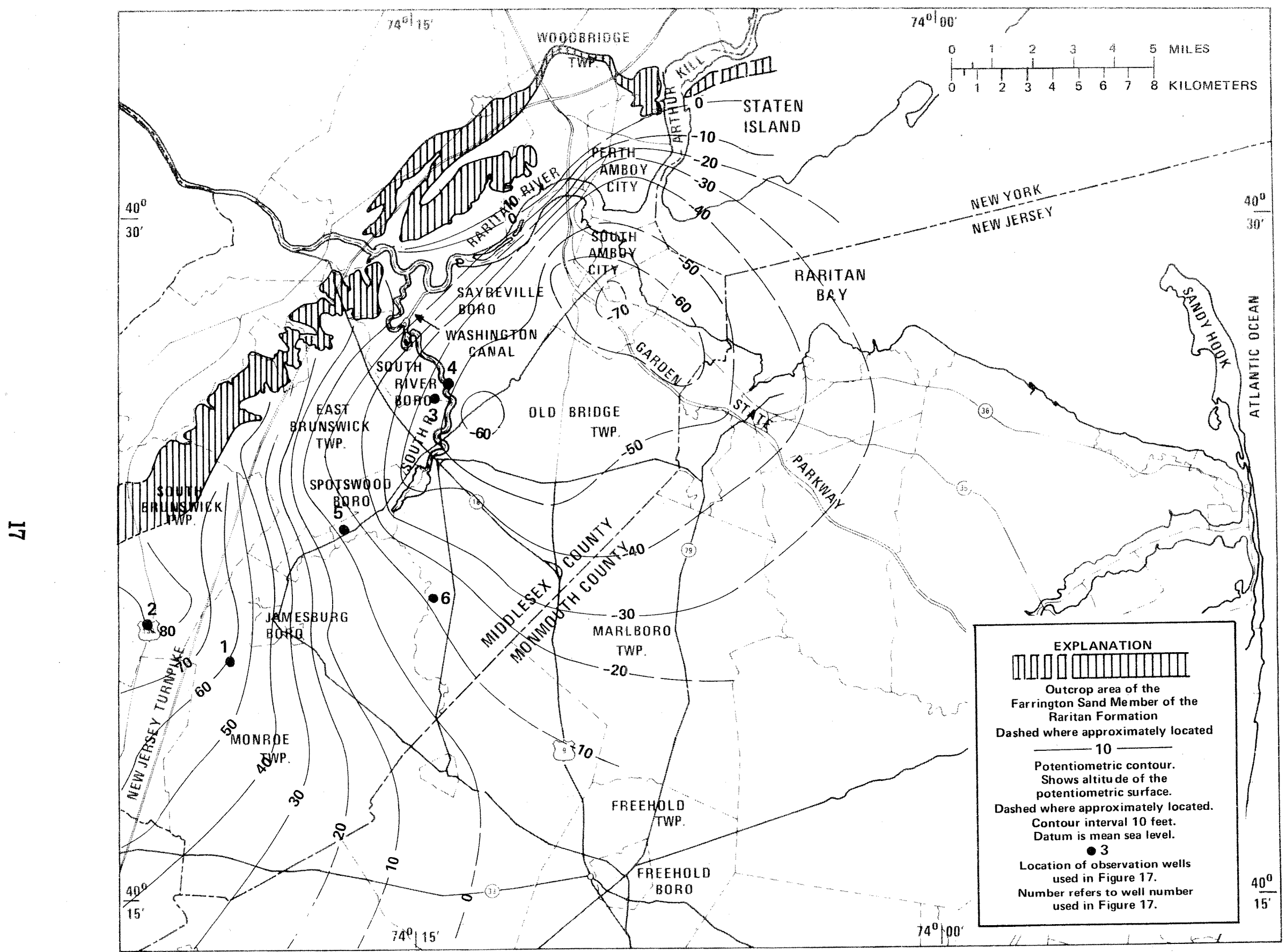

Figure 6. Potentiometric surface of the Farrington aquifer, November 1973. 


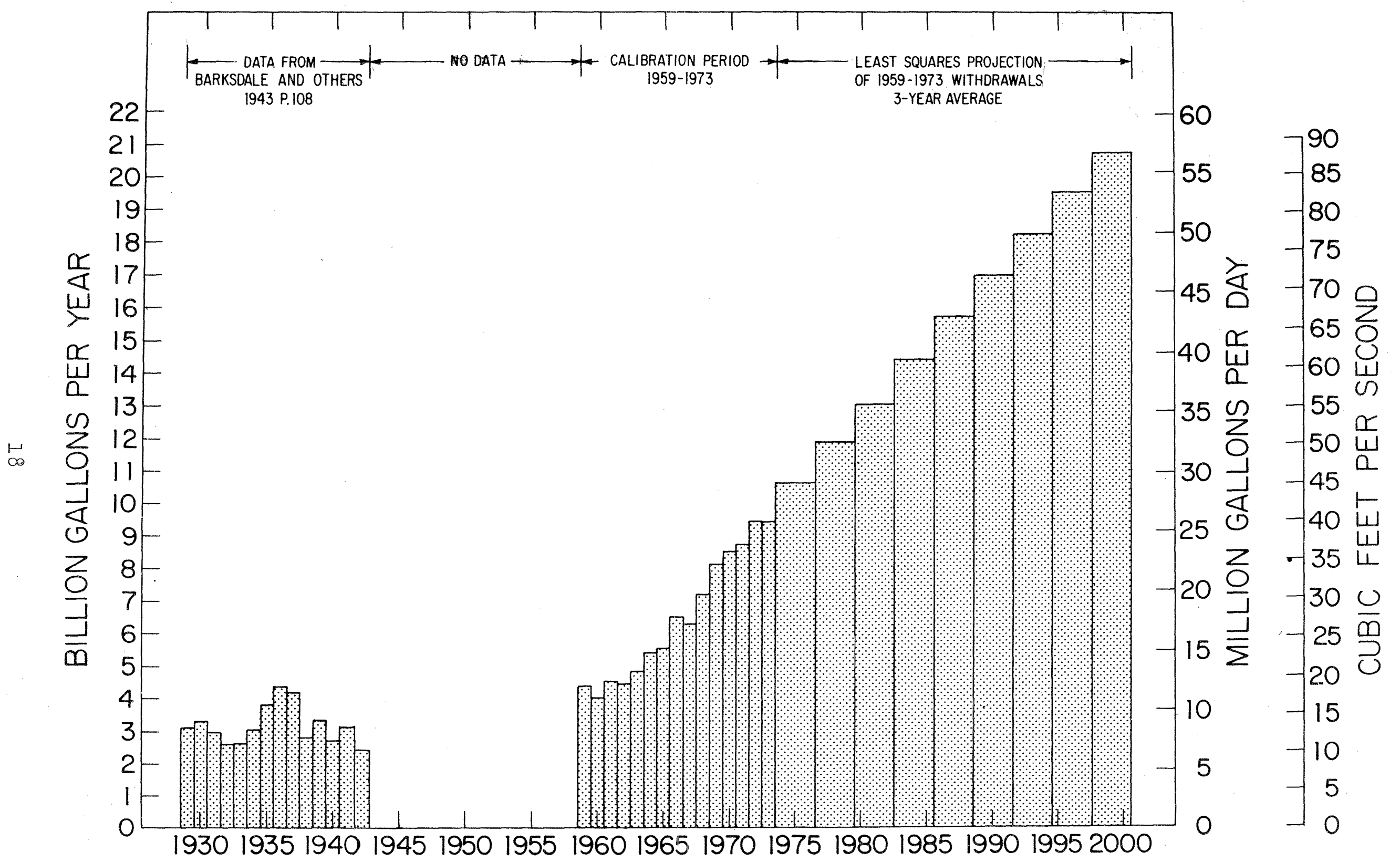

Figure 7.--Actual and projected withdrawals from the Farrington aquifer, 1929-2000. 


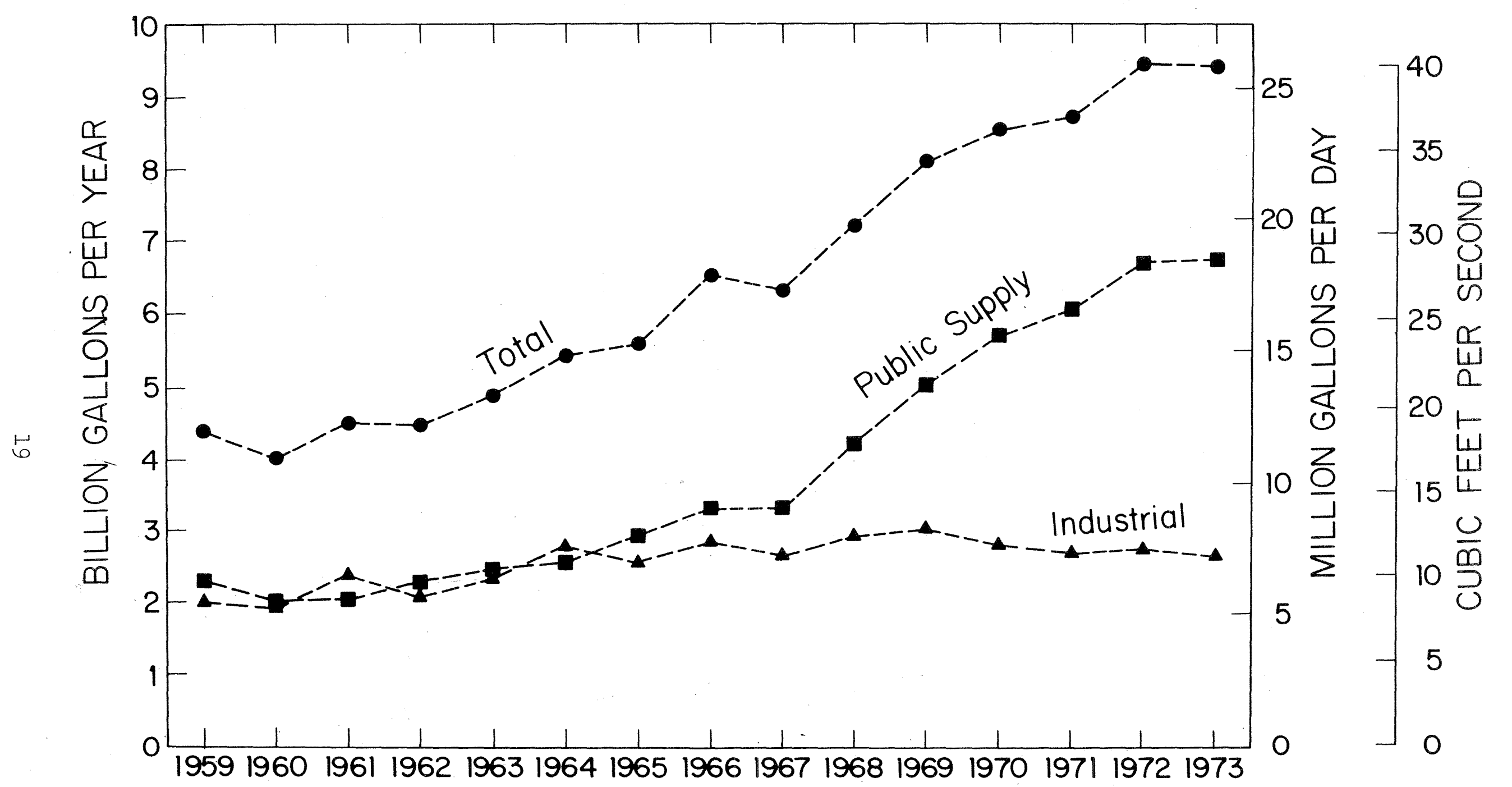

Figure 8.--Withdrawals from the Farrington aquifer, 1959-73. 
on geophysical and drillers' logs, is shown in figure 9. Although variable in thickness, the unit is generally greater than $100 \mathrm{ft}$ thick southeast of the outcrop of the Old Bridge Sand Member. The unit has a maximum thickness of $244 \mathrm{ft}$.

The Woodbridge Clay Member is a thin to thick-bedded sequence of micaceous silts and clays (Owens and Sohl, 1969, p. 239). The basal part of the Woodbridge "contains beds of compact, tough, and highly refractory fire-clay" (Barksdale and others, 1943, p. 103). This fire-clay has been mined in the vicinity of Sayreville. Also, near Sayreville, the woodbridge contains lignite, pyrite, and nodular masses of impure siderite (Barksdale and others, 1943, p. 103). To the southwest, the clay content in the Woodbridge decreases, while the sand and gravel content increases. The hydrological significance of this change in lithology will be discussed in a later section of this report.

The Woodbridge ranges in thickness from 50 to $90 \mathrm{ft}$ near the outcrop area (Barksdale and others, 1943, p. 103). Farther downdip, the thickness is $190 \mathrm{ft}$ at Fort Hancock and $120 \mathrm{ft}$ at Toms River (Perry and others, 1975, p. 1542). Perry and others (1975, p. 1543) state that the Woodbridge is "probably estuarine to shallow water marine in origin." Siderite nodules found near Sayreville in the upper part of the Woodbridge contained marine fossils suggesting a marine depositional environment for at least part of Raritan time (Barksdale and others, 1943, p. 103). Dinosaur footprints have also been found in the upper part of the Woodbridge (Barksdale and others, 1943, p. 103-104).

The Woodbridge Clay Member is widesproad throughout the Raritan Bay area (Owens and Sohl, 1969, p. 239) and has been traced from Long Island to southern New Jersey on the basis of recent palynological studies. Pollen characterizing the Woodbridge has been found in clays cropping out along the North Shore of Long Island (Sirkin, 1974, p. 440) and in clay pits near Sayreville in Middlesex County (Wolfe and Pakiser, 1971, p. B38-39). Core samples obtained from well sites at Matawan, Monmouth County, and at Fort Dix and Medford, Burlington County, have yielded this same pollen zonation (Sirkin, written commun., 1971). These sites are located 10-15 mi downdip from the outcrop area. Farther downdip, the same zonation has been found in cores collected at Fire Island State Park, Long Island; Fort Hancock, Monmouth County; and Toms River, Ocean County (Perry and others, 1975, p. 1540) as well as from cores obtained at New Brooklyn Park, Camden County, and at Milmay, Cumberland County (Sirkin, written commun., 1971).

Overlying the Woodbridge $\mathrm{Cl}$ ay Member at some locations is the Sayreville Sand Member of the Raritan Formation. The sand consists of fine to medium sand with an average thickness of 35-40 ft (Barksdale and others, 1943, p. 101-102). Locally, it is thin and clayey. Because of its irregular occurrence and its clay content, the Sayreville sand is not a significant water-producing unit. 


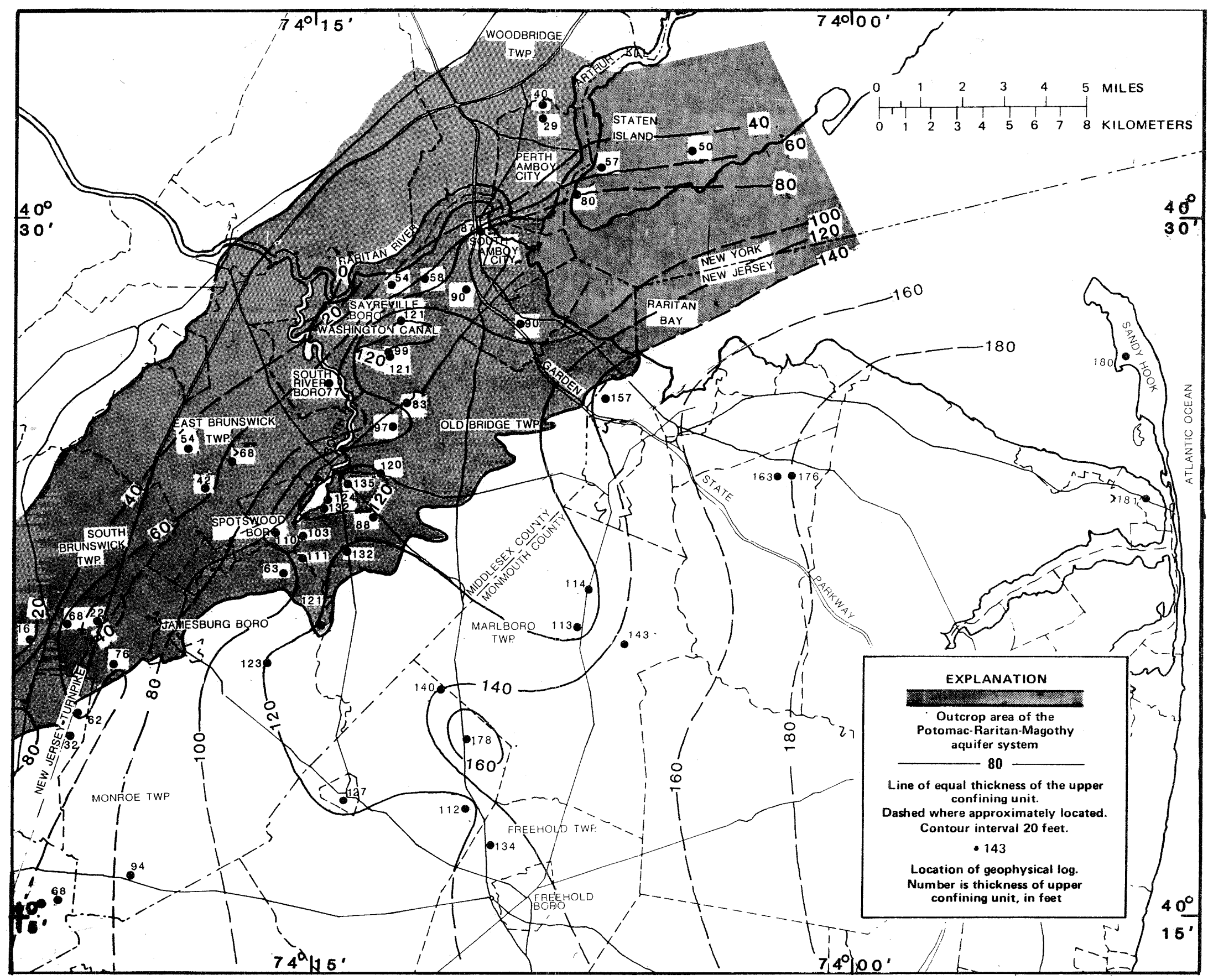

Figure 9.--Thickness of the upper confining unit. 
In parts of Sayreville Borough, where the Sayreville is missing, the South Amboy Fire Clay Member of the Raritan Formation lies directly on the Woodbridge (Barksdale and others, 1943, $p$. 102). The South Amboy Fire Clay Member consists of dark-colored silt and clay. It has a maximum thickness of $35 \mathrm{ft}$ and is lenticular. In places where the Sayreville is clayey, thin, or missing, the Woodbridge and the South Amboy act as a single confining unit between the old Bridge aquifer and the underlying Farrington aquifer.

\section{Old Bridge Aquifer}

The Old Bridge aquifer in the northern Coastal Plain of New Jersey consists primarily of the Old Bridge Sand Member of the Magothy Formation. The aquifer also includes overlying surficial sands and gravels at or near the outcrop areas (Owens and Minard, 1975). Southeast of the outcrop, where the South Amboy Fire Clay Member is thin or missing, the Old Bridge aquifer consists of the Old Bridge Sand and the underlying Sayreville Sand Members.

The Old Bridge Sand Member consists largely of light colored, medium sand and locally contains interbeds of light to dark colored, clayey silts. Owens and Sohl (1969, p. 239) have stated that the old Bridge was most likely deposited as point bar sands in river channels. The sand crops out in an irregular pattern extending from Raritan Bay to beyond Jamesburg. The thickness of the Old Bridge, ranges from 80 to $110 \mathrm{ft}$ (Barksdale and others, 1943, p. 68).

In some locations in Middlesex and Mercer Counties, surficial deposits overlie the Old Bridge (Owens and Minard, 1975). Consisting mostly of sand, these deposits increase the thickness and the effective recharge area of the Old Bridge aquifer. In the vicinity of Jamesburg, the thickness of the surficial deposits is in excess of $125 \mathrm{ft}$ with the altitude of the base of the deposits ranging from 65 to 150 ft above mean sea level (Owens and Minard, 1975).

The Old Bridge is the most productive aquifer in Middlesex and Monmouth Counties. Ground-water withdrawals from the old Bridge have caused substantial water-level declines southeast of the outcrop area. A 1959 potentiometric map using water-level data from 1958 to 1960 is shown in figure 10 and a potentiometric map using water-level measurements obtained in November 1973 is shown in figure 11. A comparison of the maps indicates that the greatest decline in water level occurred in the Freehold area in Moninouth County. 


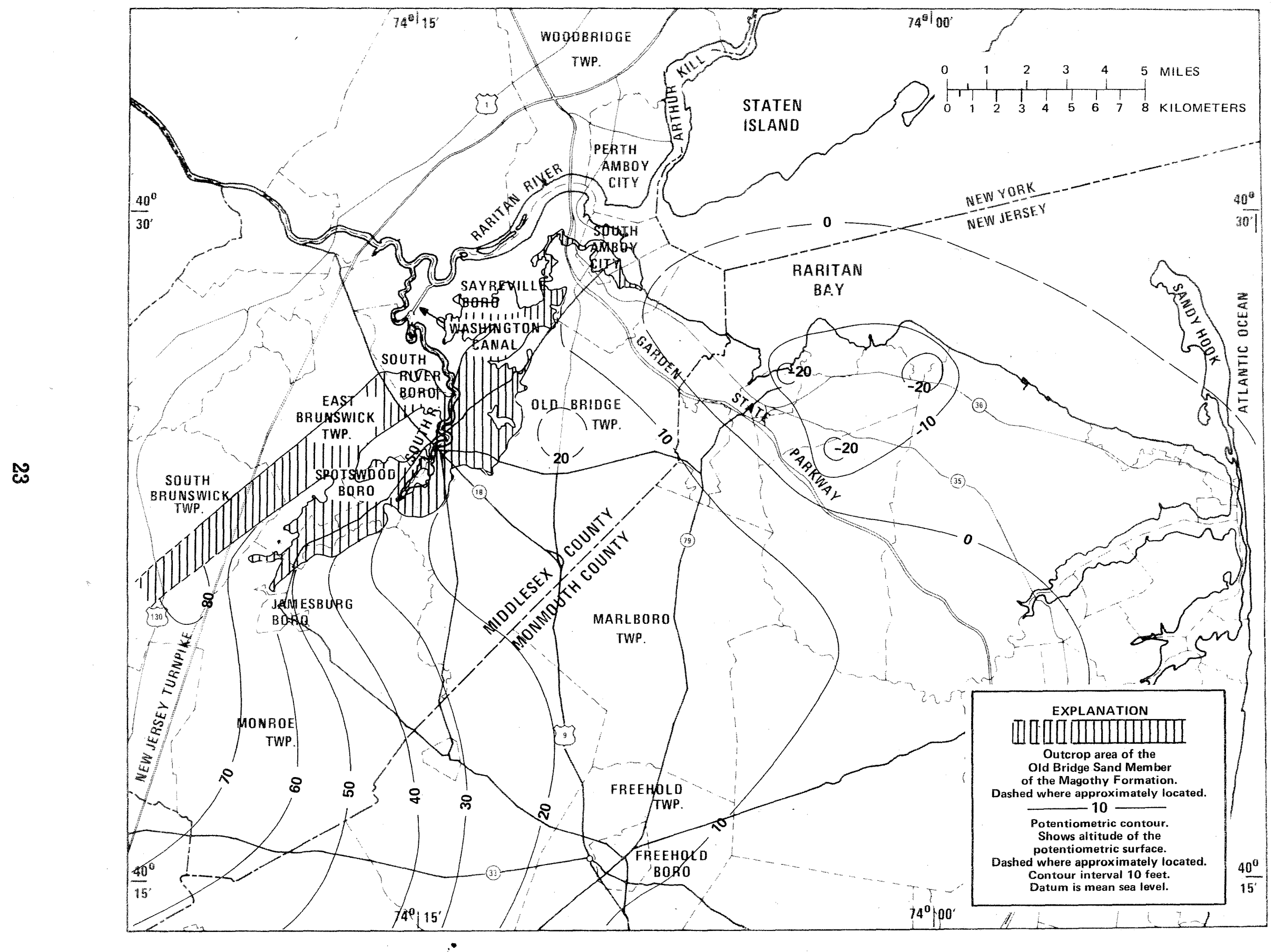

Figure 10. Generalized potentiometric surface of the Old Bridge aquifer, 1959. 


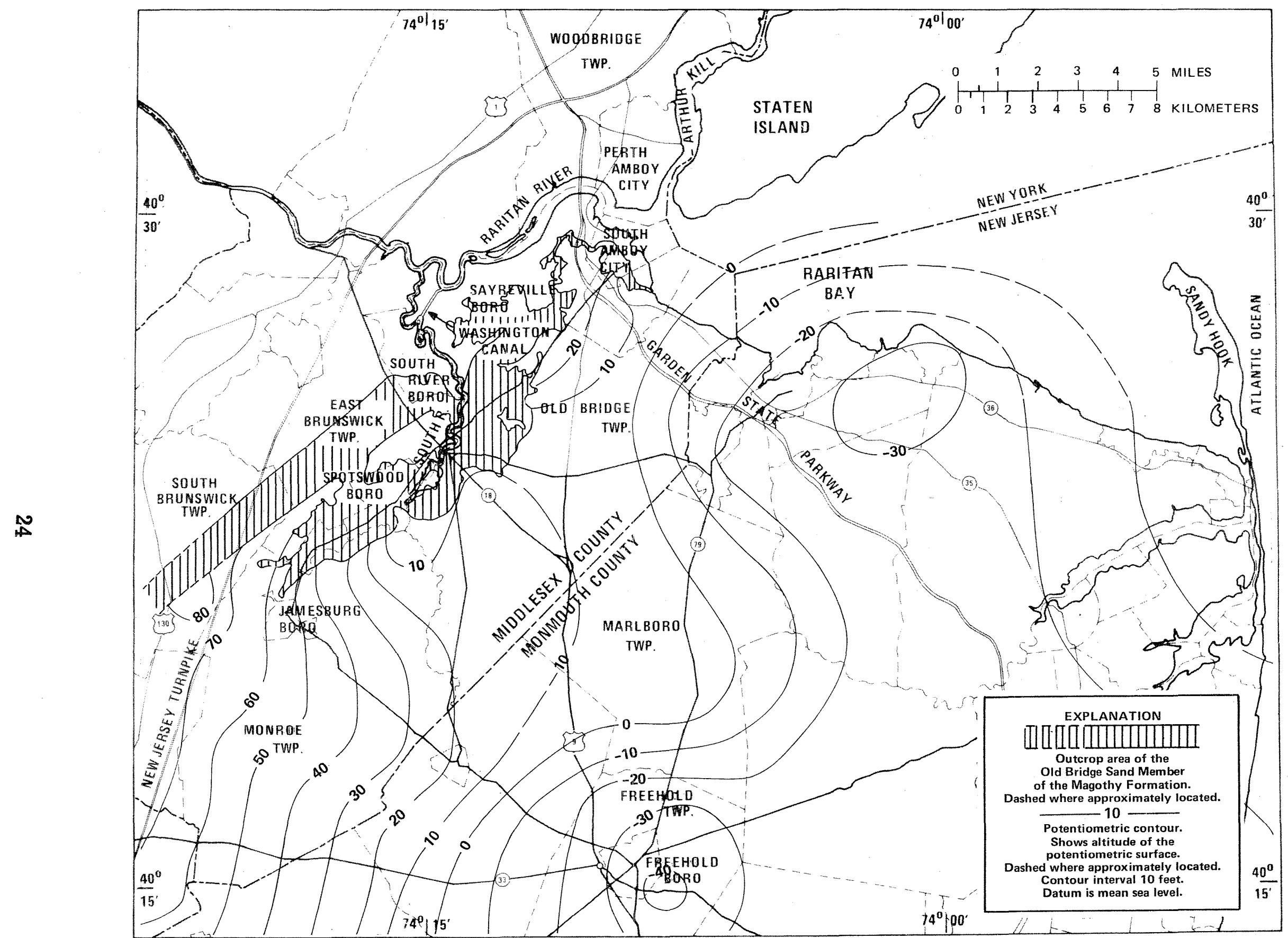

Figure 11. Potentiometric surface of the Old Bridge aquifer, November 1973. 


\section{Simulation Theory}

A two-dimensional digital-computer simulation flow model was used in this study. Finite-difference approximations were used to solve a partial differential ground-water flow equation. The model can simulate the Farrington aquifer with stresses, under water table or artesian conditions. The model assumes (1) horizontal flow within the aquifer and (2) vertical flow into and out of the aquifer from or to the overlying confining unit.

The partial differential flow equation is

$$
\begin{array}{r}
\frac{\partial}{\partial x}\left(T_{x x} \frac{\partial h}{\partial x}\right)+\frac{\partial}{\partial x}\left(T_{x y} \frac{\partial h}{\partial y}\right)+\frac{\partial}{\partial y}\left(T_{y x} \frac{\partial h}{\partial x}\right) \\
+\frac{\partial}{\partial y}\left(T_{y y} \frac{\partial h}{\partial y}\right)=S \frac{\partial h}{\partial t}+W(x, y, t)
\end{array}
$$

where

$$
\begin{aligned}
& \mathrm{T}_{x x}, \mathrm{~T}_{x y}, \mathrm{~T}_{\mathrm{yx}}, \mathrm{T}_{\mathrm{y} y} \text { are the components of } \\
& \text { the transmissivity tensor } \\
& \left(L^{2} t^{-1}\right) \text {; } \\
& \text { h is the hydraulic head (L); } \\
& S \text { is the storage coefficient } \\
& \text { (dimensionless); } \\
& W(x, y, t) \quad \text { is the volumetric flux of } \\
& \text { recharge or withdrawal per } \\
& \text { unit surface area of the } \\
& \text { aquifer }\left(\mathrm{Lt}^{-1}\right) \text {. }
\end{aligned}
$$

If the cartesian coordinates $x$ and $y$ are aligned with the principal components of the transmissivity tensor $\mathrm{T}_{\mathrm{xx}}$ and $\mathrm{T}_{\mathrm{y}}$ then the equation can be rewritten as,

$$
\frac{\partial}{\partial x}\left(T_{x x} \frac{\partial h}{\partial x}\right)+\frac{\partial}{\partial y} \quad\left(T_{y y} \frac{\partial h}{\partial y}\right)=S \frac{\partial h}{\partial t}+W(x, y, t)
$$

Under water-table conditions, transmissivity is a function of head. A change in the water level will alter the saturated thickness. Therefore, transmissivity is replaced by the product of the hydraulic conductivity and the saturated thickness, and the flow equation

$$
\frac{\partial}{\partial x} \quad\left(K_{x x} b \frac{\partial h}{\partial x}\right)+\frac{\partial}{\partial y}\left(K_{y y} b \frac{\partial h}{\partial y}\right)=S_{y} \frac{\partial h}{\partial t}+W(x, y, t)
$$


where

\begin{tabular}{|c|c|c|}
\hline$K_{x x}, K_{y y}$ & & $\begin{array}{l}\text { are the principal components } \\
\text { of the hydraulic conductivity } \\
\text { tensor }\left(L^{-1}\right) \text {; }\end{array}$ \\
\hline $\mathrm{b}$ & & $\begin{array}{l}\text { is the saturated thickness of } \\
\text { the aquifer (L); }\end{array}$ \\
\hline $\mathrm{h}$ & . & is the hydraulic head (L); \\
\hline $\mathrm{S}_{\mathrm{y}}$ & & $\begin{array}{l}\text { is the specific yield of } \\
\text { the aquifer (dimensionless); }\end{array}$ \\
\hline$w(x, y, t)$ & & $\begin{array}{l}\text { is the volumetric flux of } \\
\text { recharge or withdrawal per } \\
\text { unit surface area of the } \\
\left.\text { aquifer ( } \mathrm{Lt}^{-1}\right) \text {. }\end{array}$ \\
\hline
\end{tabular}

Vertical leakage from an overlying confining unit is calculated by a quasi-three-dimensional method (Bredehoeft and Pinder, 1970). Vertical leakage is approximated based on the assumptions that heads in the aquifer overlying the confining unit are constant and there is no lateral flow in the confining unit.

Trescott's (1973) simulation program was used for this study. It allows the simulation of an aquifer under water-table and artesian conditions and includes the quasi-three dimensional method of calculating vertical leakage. However, to obtain a better simulation the program was modified to allow the simuiated head overlying the confining unit to be lowered at any specified rate. The 1959 potentiometric surface of the old Bridge aquifer was used in the model as the starting head overlying the confining layer. Thereafter, the simulated Old Bridge head at each node was adjusted at the beginning of each time step at a rate equal to the average rate of head change that occurred at the respective node location from 1959 to November 1973. The head change in the aquifer used in the model was generally less than $1 \mathrm{ft} / \mathrm{yr}$ and none of the nodes had a rate that exceeded $3 \mathrm{ft} / \mathrm{yr}$. Therefore, the method of calculating vertical leakage (Bredehoeft and Pinder, 1970 ) is probably applicable, because the rate of head change overlying the confining unit is relatively small.

Another modification of the simulation program was made so that hydraulic heads at nodes along the southwestern boundary were adjusted at each time step at a specified rate. The rate is based on estimated head declines occurring at the boundary from 1959 to November 1973.

\section{Model Application}

The digital-simulation model of the Farrington aquifer was developed to evaluate the water-bearing capabilities of the Farrington aquifer and to determine the change in the potentio- 
metric head resulting from water withdrawal and (or) recharge. In order to apply the digital computer program to the Farrington aquifer, the following hydrologic factors must be specified: (1) boundary conditions; (2) initial water-level conditions; (3) aquifer parameters; (4) recharge and withdrawal stresses; and (5) confining unit parameters. Using these conditions and parameters, the model computes heads at specific times at all nodes. The resulting changes in potentionetric head are compared with generalized water-level declines based on field data and with selected hydrographs of existing wells. Trial and error procedures were used to modify the selected parameters within reasonable ranges. This method was used to calibrate the model.

The modeled area was divided into a rectangular finitedifference grid having 41 rows and 48 columns, resulting in 1,968 rectangular cells or nodes. Each node is characterized by at least ten hydrologic parameters. A variable rectangular grid was used in order to provide greater accuracy in a fine-grid area containing the greatest concentration of production wells and hydrologic data. The fine-grid area, (fig. 12), has a node spacing of $0.5 \mathrm{mi}$ and a total area of $306 \mathrm{mi}^{2}$. Nodes increase in size away from the fine-grid area in three directions with the largest node $32 \mathrm{mi}$ long in each direction. The total area covered by the grid is over $7,500 \mathrm{mi}^{2}$.

\section{Boundary Conditions}

The model uses three types of boundaries: (1) constant head at a given node for the entire simulation; (2) an impermeable boundary between two adjacent nodes; and (3) specified head at a node at a given time.

The northwestern model boundary, representing the featheredge of the aquifer outcrop is designated as an impermeable boundary. The northeastern boundary, located in the Long Island area $70 \mathrm{mi}$ from Middlesex County, and the southeastern boundary, located approximately $60 \mathrm{mi}$ offshore of the New Jersey coast, are also designated as impermeable boundaries, because the northeastern and southeastern boundaries are located sufficiently far from the withdrawal centers so that they would have minimal effect on the water-level in the fine-grid area. In addition, recent offshore geophysical investigations have suggested that a major regional fault paralleling the coastline approximately 75 to $90 \mathrm{mi}$ off the coast of New Jersey probably exists (Mattick and others, 1975, $p$. 99 and plate 3). The regional fault might offset the Farrington aquifer so that the aquifer abuts a confining unit thereby creating a no-flow boundary to the southeast.

The southwestern boundary was defined in a way that permits the effects on ground-water flow caused by stress in the part of the aquifer underlain in the counties to the southwest of the study area to be included in the simulation without physically including them in the model. To achieve this goal, the potentiometric head in the Farrington aquifer at all nodes in 


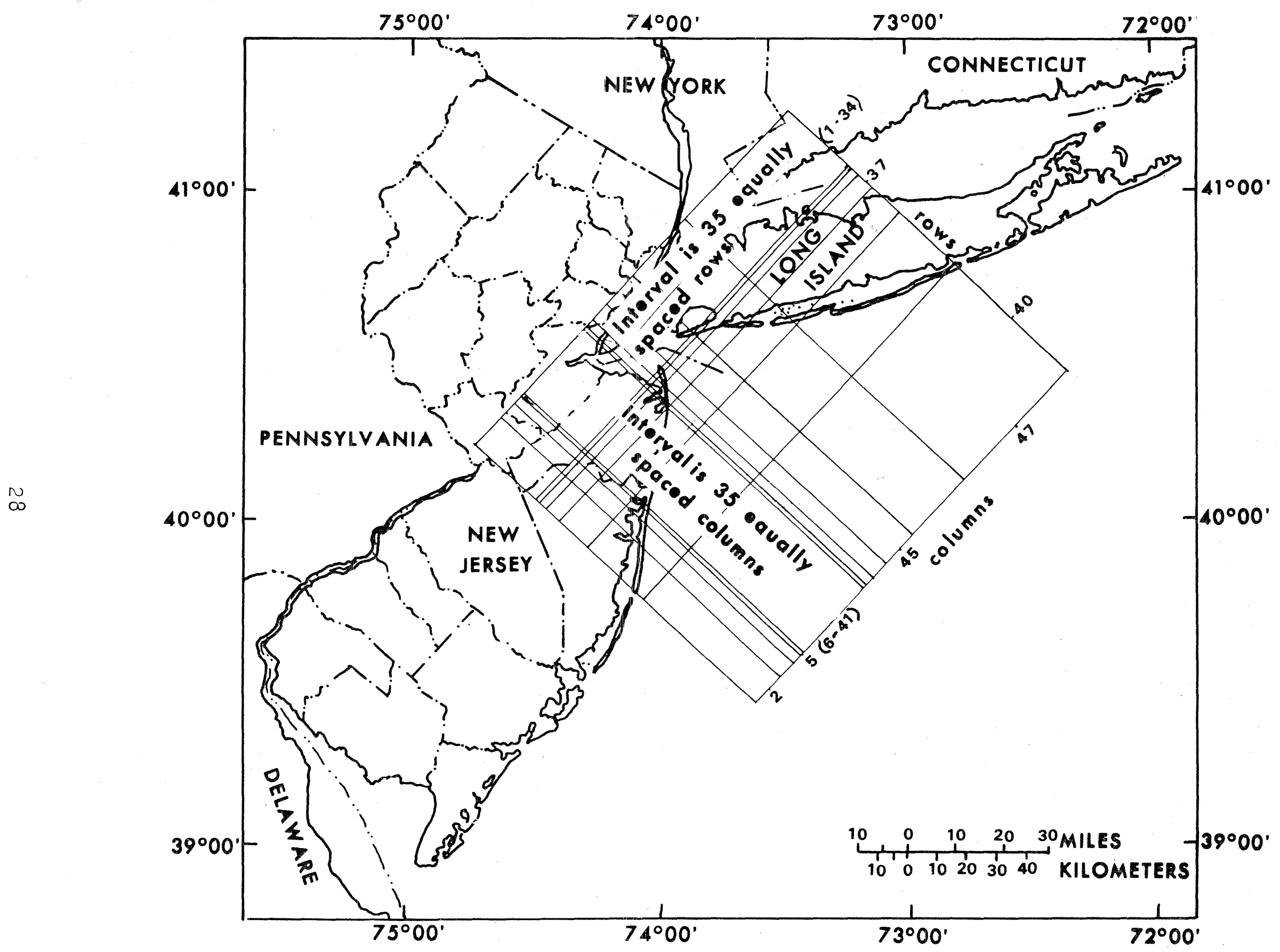

Figure 12.--Index map of New Jersey showing variable rectangular grid used for the 'simulation model. 
column 2 of the finite difference grid (fig. 12) is specified at each time step and kept as a constant head during the time step. The initial head is based upon the actual 1959 potentiometric head in the Farrington aquifer. Thereafter, the head is adjusted at the beginning of each time step for almost every node in the second column. The adjusted head is lowered at a specified rate determined by the actual or estimated decline in head that occurred in the aquifer during the period from 1959 to November 1973. In addition, each node in column 2 is assigned a very large value of storage coefficient (1040) to keep the head constant during a time step. Simulation of future potentiometric surfaces requires that future head values or a future rate of head decline be specified for the southwestern boundary.

The model treats bodies of water in and near the outcrop area as constant head nodes. A total of eight constant head nodes were assigned representing the Raritan River, Arthur Kill, and the Washington Canal. The row and column location of these nodes are:

$\begin{array}{ccc} & \text { Row } & \text { Column } \\ \text { Raritan River } & 3 & 26 \\ & 4 & 25 \\ & 6 & 30 \\ \text { Arthur Kill } & 6 & 31 \\ & 6 & 32 \\ \text { Washington Canal } & 8 & 41 \\ & 9 & 40\end{array}$

Initial Conditions

Initial conditions are specified so that transient flow occurs at the start of the simulation. Simulated water levels will respond not only to the stress of the pumping wells but also to the initial conditions set forth.

The initial potentiometric surface used in the model is the 1959 potentiometric surface of the Farrington aquifer (fig. 5). The potentiometric surface for the area offshore of New Jersey was estimated. The potentiometric surface for the Long Island area was based on data reported by Kimmel (1973).

The initial potentiometric surface of the aquifer overlying the confining unit is the 1959 potentiometric surface of the old Bridge aquifer (fig. 10). In areas where data were lacking, the potentiometric surface was estimated.

\section{Aquifer Characteristics}

Aquifer characteristics that are required for simulation of the Farrington aquifer as both a water table and an artesian 
aquifer include the following: (1) altitude of the top and bottom of the aquifer; (2) lateral hydraulic conductivity of the aquifer; (3) specific yield of the water-table aquifer; and (4) storage coefficient of the artesian aquifer.

The altitude of the top of the Farrington aquifer shown in figure 2 was used to specify the altitude of the top of the aquifer at each node. The thickness map shown in figure 3 was used as a basis to compute the altitude of the bottom of the aquifer at each node. In the nearshore and offshore areas and in Long Island, both the thickness and the altitude of the top of the aquifer were estimated.

Because the Trescott (1973) program considers only lateral flow occurring in aquifers, only lateral hydraulic conductivity of the Farrington aquifer was used. No significant vertical head differences were found in the study area; therefore, the assumption made in the Trescott program is acceptable.

Specific capacity per foot of screen was used to estinate the lateral hydraulic conductivity because only a few aquifer test results were available. The equation used in the estimation is

where

$$
\mathrm{K}_{\mathrm{L}}=1.1 \frac{\mathrm{Q}}{\mathrm{sd}}
$$

$\mathrm{K}_{\mathrm{L}}$
$\mathrm{Q}$
$\mathrm{s}$
$\mathrm{d}$

is lateral hydraulic conductivity $(\mathrm{L} / \mathrm{T})$;

is well discharge $\left(L^{3} / T\right)$;

is drawdown in well (L);

is length of screened interval in well (L).

This equation was developed from the Thiem equation for steadystate radial flow (Bennett, $1976, \mathrm{p} .8$ ). The term Q/sd is defined as specific capacity per foot of screen. A mean value for $Q / s d$ of 0.62 (gal/min)/ft per foot of screen determined from 99 wells was used in the above equation. A lateral hydraulic conductivity of $132 \mathrm{ft} / \mathrm{d}$ was obtained. This value was initially used for all nodes except in areas: (1) where the Farrington Sand Member is replaced by relatively impermeable river mud along the Raritan River from the mouth of Lawrence Brook to Perth Amboy and along Arthur Kill between New Jersey and Staten Island; (2) where the Farrington Sand Member is missing or relatively thin owing to a lack of deposition on the Triassic diabase sill; and (3) offshore in the vicinity of the southeastern boundary of the model. Data obtained from a deep test hole located approximately $85 \mathrm{mi}$ offshore indicate that the sediments equivalent to the Farrington are cemented sandstones (Rhodehamel, 1977, p. 18).

The transmissivity of the Farrington aquifer is calculated by multiplying the lateral hydraulic conductivity by the saturated thickness. The transmissivity varies from node to node and changes with time in the water-table part of the aquifer. The transmissivity values used are shown in figure 13. The values 


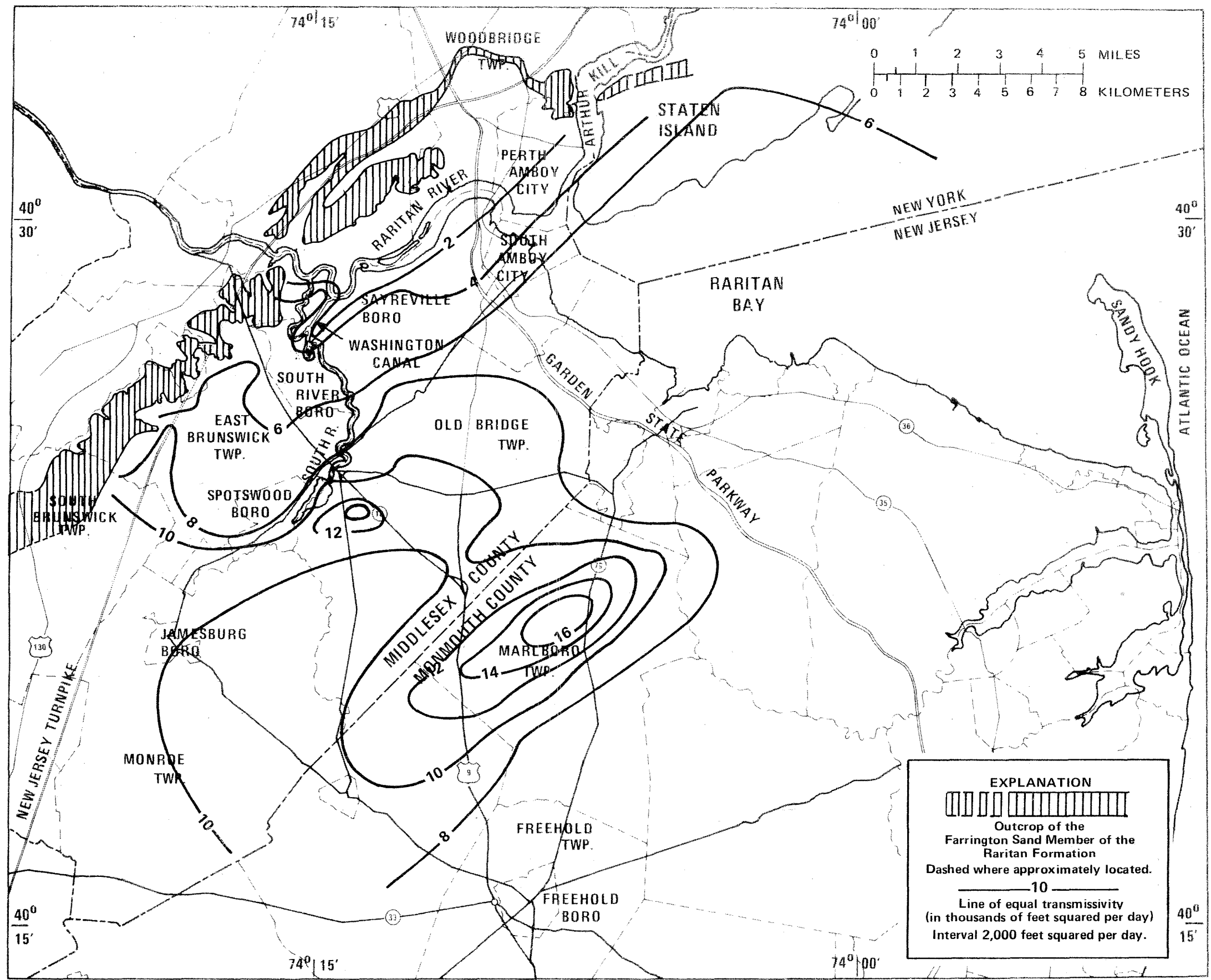

Figure 13. Transmissivity of the Farrington aquifer used in the simulation model. 
range from a low of $42 \mathrm{ft}^{2} / \mathrm{d}$ in the vicinity of the Triassic diabase sill near the Raritan River to a high of $16,800 \mathrm{ft}^{2} / \mathrm{d}$ just south of the Middlesex-Monmouth County line. Most of the eastern part of the area shown in figure 13 has transmissivity values ranging between 6,000 and $8,000 \mathrm{ft}^{2} / \mathrm{d}$.

The model assigns uniform values for specific yield and storage coefficient of 0.25 and $1.6 \times 10^{-4}$, respectively. The assumed specific yield is within the range of specific yield values given by Lohman (1972, p. 53-54.). It is also close to the 0.23 value determined by Rhodehamel (1970, p. 24) for the Cohansey Sand in the Pine Barrens region. Barksdale and others (1943, p. 84) indicate that the Farrington is roughly comparable to the Cohansey. When the model calculates the hydraulic head of the Farrington to be lower than the altitude of the top of the Farrington aquifer, the storage coefficient is replaced by specific yield.

The assumed storage coefficient is close to the values obtained from aquifer tests discussed in the section of hydraulic characteristics of the Farrington aquifer, and also is within the guidelines for storage coefficient values given by Lohman (1972, p. 53 ).

\section{Recharge and Withdrawal}

Recharge was simulated by placing recharge wells at nodes in the outcrop area. Recharge at a node was proportionally reduced if part of the node represents areas outside of the outcrop. A constant recharge rate of $5.2 \mathrm{in} / \mathrm{yr}$ is used in the model. This rate is equivalent to $0.4\left(\mathrm{ft}^{3} / \mathrm{s}\right) / \mathrm{mi}^{2}$. Total recharge to the outcrop for each time step was approximately $8 \mathrm{ft}^{3} / \mathrm{s}$. Barksdale (1937, p. 15-16) suggests that, on the basis of an annual precipitation of 46 inches and an average runoff of 18 to 22 inches, only 4 to 8 inches per year are available for ground-water recharge. However, Barksdale (1937, p. 16) further states that based on conditions south of the Raritan River, the amount of water recharged is "nearer 20 inches per year than 4 to 8 inches." The author believes that 4 to 8 inches per year ( 9 to 17 percent of average annual precipitation) is a more realistic estimate of average annual recharge than 20 inches per year ( 43 percent of average annual precipitation).

Ground-water withdrawal rate in cubic feet per second is assigned to nodes representing production wells tapping the Farrington aquifer. Almost all of the nodes having active production wells are located in the fine-grid area.

During most simulation runs, a withdrawal scheme consisting of five 3-year periods was used to reduce computer costs. Withdrawal during each period was the average annual rate of the three years. In final simulations, however, fifteen 1-year withdrawals (1959-73) were used to obtain a more accurate simulation of water-level declines. 
Withdrawal values for 1959 and 1973, are presented in figure 14. Heavy concentration of pumping in a $14 \mathrm{mi}^{2}$ area near Old Bridge is indicated by a withdrawal of $6.9 \mathrm{Mgal} / \mathrm{d}\left(10.7 \mathrm{ft}^{3} / \mathrm{s}\right)$ in 1959, representing 57 percent of the total 1959 withdrawal from the aquifer. The withdrawal was $10.6 \mathrm{Mgal} / \mathrm{d}\left(16.4 \mathrm{ft}^{3} / \mathrm{s}\right)$ in 1973 and represented 41 percent of the total 1973 rate.

\section{Confining Unit Characteristics}

The model simulates the aquifer with two confining units. The lower confining unit is assumed to be an impermeable unit. Northwest of the Middlesex-Monmouth County line, the lower confining unit consists of bedrock overlain by a clay unit. Southeast of the county line, information regarding the sand below the lower confining unit is limited and no water was obtained from the sand during the calibration period, 1959-73.

The upper confining unit consists mainly of the Woodbridge Clay Member. The unit, where present, ranges in thickness from 10 to $200 \mathrm{ft}$ ( $\mathrm{fig} .9$ ). A uniform specific storage of $4 \times 10^{-5} \mathrm{ft}^{-1}$ is used in the simulation model. Calibration runs of the model indicated that specific storage is one of the least sensitive parameters in the model.

Data on the vertical hydraulic conductivity of the upper confining unit are sparse. Observations of plastic clays in clay pits near Sayrevilie and the examination of a long-term aquifer test, as well as geologic logs for sites in South Brunswick Township, core samples, and geophysical logs, suggest a wide range in vertical hydraulic conductivity. Vertical hydraulic conductivity used in the model ranges from $4.2 \times 10^{-1} \mathrm{ft} / \mathrm{s}$ in South Brunswick Township to $1.0 \mathrm{x} 10^{-10} \mathrm{ft} / \mathrm{s}$ in the Sayreville area. The selected values were determined by testing a range of values during model runs.

In addition to the Woodbridge Clay Member, bottom sediments beneath Farrington Lake, Westons Pond, and three streams that traverse the outcrop area south of the Raritan River were simulated as part of the upper confining unit. Lakebed and streambed thicknesses were estimated and a vertical hydraulic conductivity of $4.2 \times 10^{-7} \mathrm{ft} / \mathrm{s}$ was assigned.

\section{Vertical Leakage}

Vertical leakage from the upper confining unit was approximated as 1) steady leakage through the unit, and 2) transient leakage from storage within the unit. Results of the simulation runs indicate that the major component of vertical leakage is steady leakage. A computer run was made with the specific storage of the confining unit equal to zero, thus allowing vertical leakage to occur only as a steady leakage. The results of the run were compared with another run in which the specific storage was equal to $4 \times 10^{-5} \mathrm{ft}^{-1}$. The difference in 


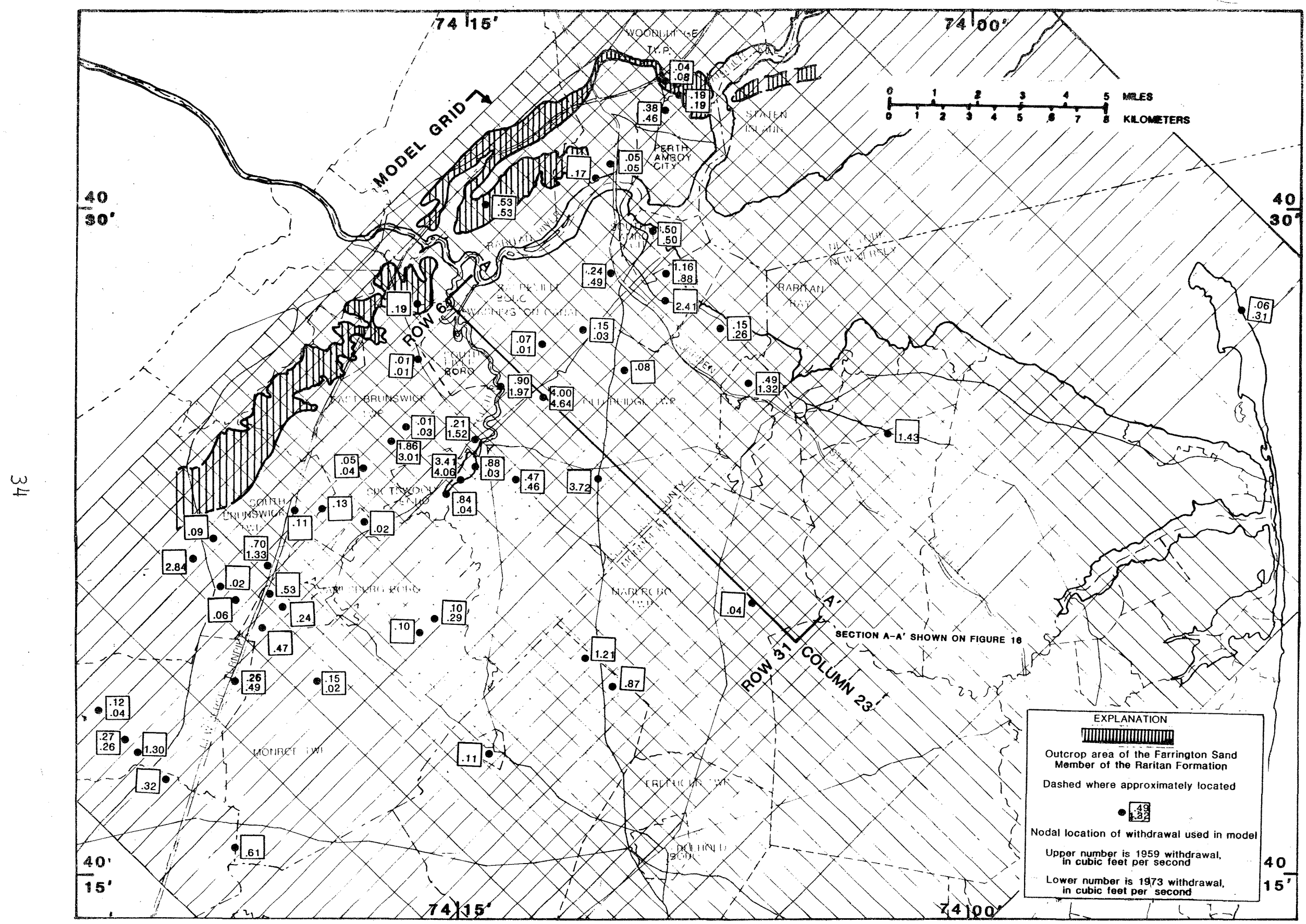

Figure 14.--Distribution of withdrawals from the Farrington aquifer, 1959 and 1973. 
head between the two runs at the end of 15 years was approximately 1 foot or less, revealing that the transient component of vertical leakage has only a small effect on heads for the 15-year period.

The amount of vertical leakage from or to the Old Bridge aquifer is dependent upon the difference between the Farrington head and the old Bridge head. The thickness, specific storage, and vertical hydraulic conductivity of the upper confining unit also determine the amount of leakage. The direction of leakage is dependent on the head relation of the Farrington and Old Bridge aquifers. In much of Middlesex County, the Old Bridge heads during the 15-year period 1959 through 1973 were higher than those in the Farrington aquifer, resulting in downward leakage into the Farrington. However, southeast of the Middlesex-Monmouth County line, Old Bridge heads were lower than Farrington heads, especially in the Freehold area. This head difference during the 15-year period caused vertical leakage into the old Bridge to occur.

Vertical leakage from surface-water bodies is also sinulated. These surface-water bodies represent Farrington Lake, Westons Pond, and three streams that traverse the outcrop of the Farrington, south of Raritan River. The direction of leakage is downward. The amount of leakage is dependent on the head difference between the Farrington and the water level in the surface-water bodies, as well as the thickness, specific storage, and vertical hydraulic conductivity of the lakebed or streambed sediments.

\section{Model Calibration}

Transient Simulation

The model was calibrated for transient conditions by making adjustments in several of the hydrologic parameters in order to provide satisfactory agreement between the simulated and actual potentiometric surfaces. The potentiometric surface generated by the model at the end of the 15-year period (1959-73) was compared with the observed November 1973 potentiometric surface. Hydrographs of water levels in selected wells were also compared with the model hydrographs. The calibration was made by matching the calculated head changes with observed head changes under a known stress during the 15-year period.

Hydrologic parameters were adjusted during calibration, in order to better fit the calculated potentiometric surface to the observeol surface. The parameters that were adjusted were lateral hydraulic conductivity, vertical hydraulic conductivity of the confining unit, recharge, and specific yield.

The uniform lateral hydraulic conductivity of the Farrington aquifer was reduced from 132 to $105 \mathrm{ft} / \mathrm{d}$. An additional 25 percent reduction in the lateral hydraulic conductivity was made for a small area in Sayreville Borough and Old Bridge. Township. 
The reduction probably could be justified by two observations. First, most well drillers attempt to screen only part of the aquifer having the greatest potential hydraulic conductivity. Therefore, an average hydraulic conductivity for the aquifer would be somewhat less than the value computed by using the screen length and specific capacity of the well. Second, many of the 99 wells used in the determination of the hydraulic conductivity are located near the outcrop where the aquifer consists, in part, of coarse sand and some gravel. Downdip, the aquifer consists of a medium to fine sand. The average specific capacity per foot of screen for the aquifer would most likely decrease in a southeasterly direction from the outcrop. This type of pattern has been noted for the Potomac-Raritan-Magothy aquifer system in Camden County (Farlekas and others, 1976, p. 39). It is believed that if specific capacity data were available for the area to the southeast, a similar decrease in values would be evident.

Vertical hydraulic conductivity of the upper confining unit was adjusted extensively during calibration. Values ranging from $4.2 \times 10^{-7} \mathrm{ft} / \mathrm{s}$ in the South Brunswick Township area to $1.0 \mathrm{x}$ $10^{-10} \mathrm{ft} / \mathrm{s}$ in the Sayreville area were used. Specific storage of $4 \times 10^{-5} \mathrm{ft}^{-1}$ and thickness of the upper confining unit were not modified.

Uniform values of specific yield and recharge were varied to determine the effect of different values. The calibrated model uses 0.25 for specific yield and a recharge rate of 5.2 in/yr $\left[0.25(\mathrm{Mgal} / \mathrm{d}) / \mathrm{mi}^{2}\right]$. The aquifer storage coefficient of $1.6 \mathrm{x}$ $10^{-4}$ was not modified.

The simulation results are shown in figure 15 (potentiometric surface), figure 16 (cross section of head profile), and figure 17 (hydrographs of selected wells). A comparison of the November 1973 observed potentiometric surface with the simulated year-end 1973 surface (fig. 15) shows the best fit occurs in the center of the cone of depression in Middlesex County. Near Raritan Bay, the fit is not as good. This may be due to lack of adequate waterlevel data. A cross section from the outarop near the Washington Canal through the center of the cone of depression in Sayreville, just southeast of Marlboro Township in Monmouth County (fig. 16), also reveals a good fit between the observed and calculated water levels for 1973 .

Hydrographs that were compared with model results, inaicate the results are adequate (fig. 17). Water levels are not available for the entire period (1959-73) for all wells.

\section{Steady-state Simulation}

After calibration, a steady-state simulation was made in an attempt to determine the shape of the prepumping potentiometric surface. During the simulations, the storage coefficient and specific yield were set to zero and a recharge rate of $5.2 \mathrm{in} / \mathrm{yr}$ was used. The 1959 Old Bridge potentiometric surface was used as 


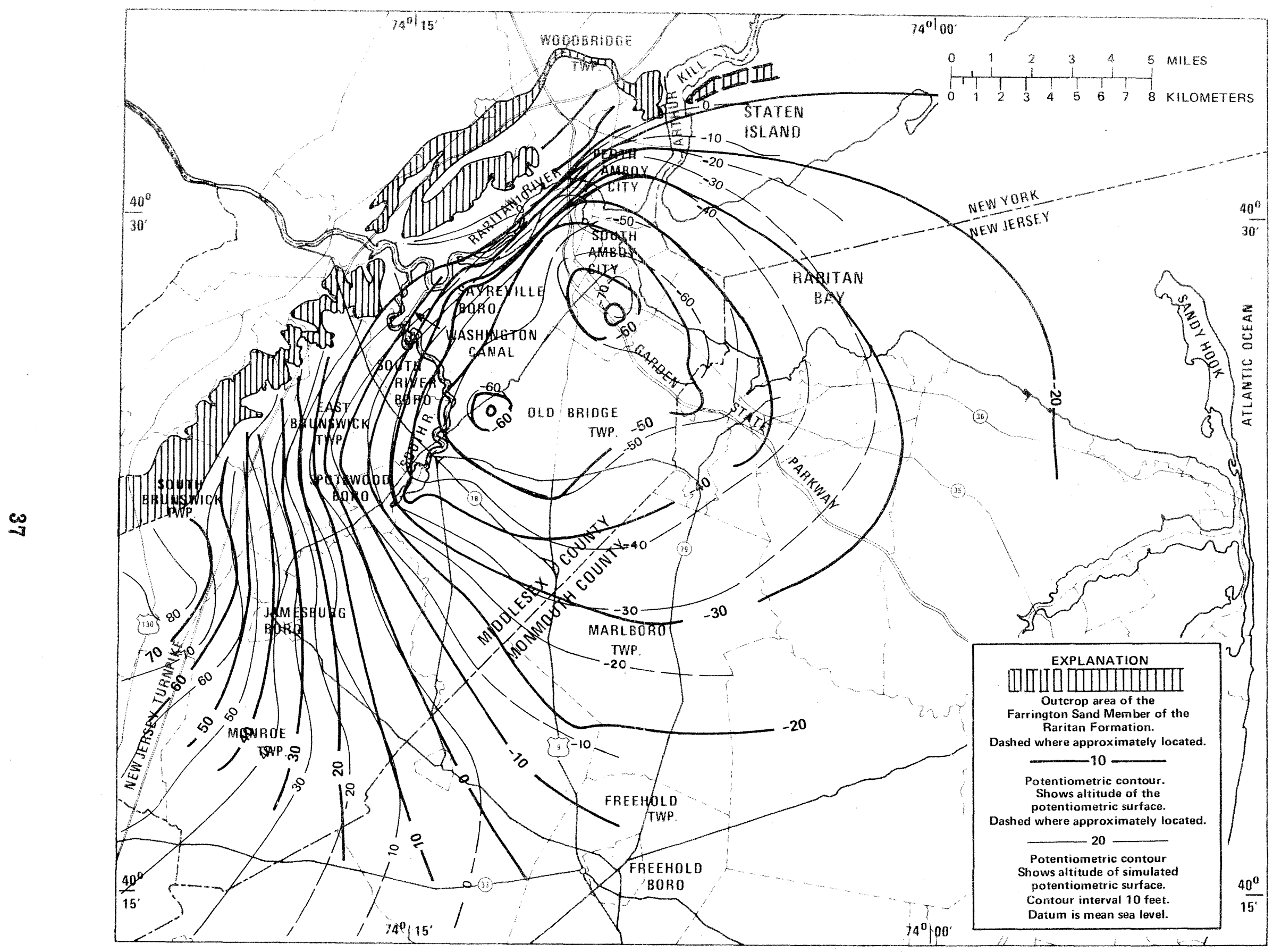

Figure 15. Measured (November 1973) and simulated (vear end 1973) potentiometric suriace of the Farrington aquifer. 


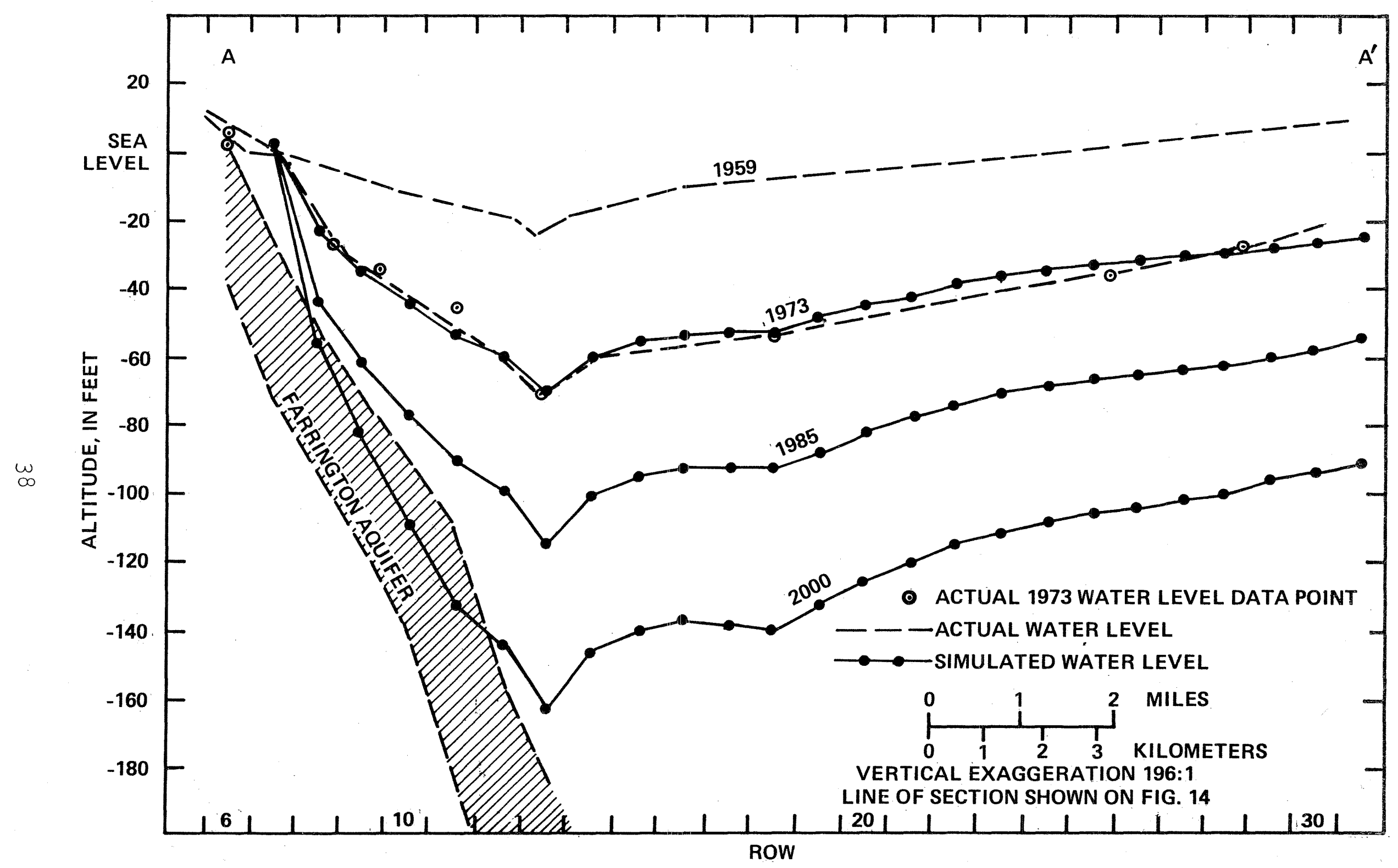

Figure 16.-_Cross section of the measured potentiometric surface, 1959 and November 1973, and simulated potentiometric surface for year end 1973, 1985, and 2000. 

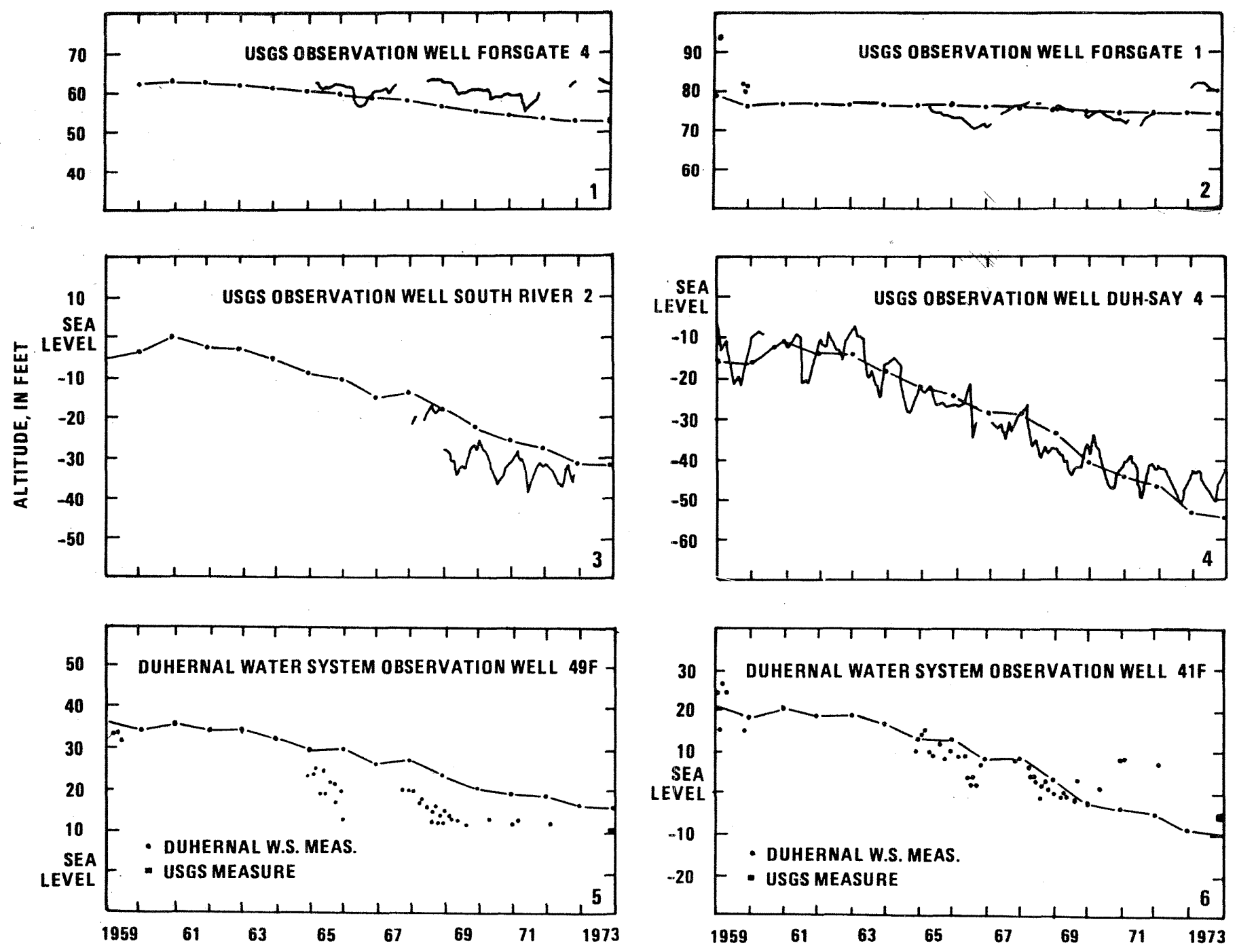

EXPLANATION

$\checkmark$ (RECORDER) OR $\because \therefore:$ (TAPE) HISTORIC WATER-LEVEL HYDROGRAPH

MODEL-GENERATED WATER-LEVEL HYDROGRAPH LOCATION OF WELLS SHOWN IN FIGURE 6 . WELL NUMBERS USED IN FIG URE 6 ARE GIVEN IN LOWER RIGHT CORNER.

Figure 17.--Hydrographs of observed and simulated water levels in selected wells, 1959-73. 
input for the steady-state runs.

The simulated head distribution in the aquifer is shown in figure 18. No measured prepumping potentiometric surface is available for comparison. However, head in the Perth Amboy well rield located in Sayreville observed in 1897 was about 35 or $40 \mathrm{ft}$ above sea level (Barksdale, 1937, p. 1). The computer calculated water level in the same area is $37 \mathrm{ft}$ above sea level. Despite lack of data on prepumping water levels, it is believed that the simulated steady-state potentiometric surface reasonably approximates the prepumping head distribution in the Farrington aquifer.

\section{Accuracy of Data}

The accuracy of data used in the model varies considerably from place to place. Depths to water level were obtained by tape in observation wells and by air line in some production wells. They were then converted to mean sea level datum using, in some cases, surveyed altitude of the measuring point and, in other cases, estimates from topographic maps having contour intervals of 10 or $20 \mathrm{ft}$. Therefore, the estimated altitude of the measuring points may be in error by as much as $10 \mathrm{ft}$. Water levels were contoured interpretively and then digitized for model input thus providing sources of inaccuracies, especially in areas having steep gradients. Geophysical data used to construct the top and thickness of the Farrington aquifer and the overlying confining unit are also subject to errors involved in the altitude estimation.

Ground-water withdrawal data also may contain errors because some water users did not keep accurate records. In some cases users supplied total withdrawal data for well fields tapping both the Old Bridge and Farrington aquifers, but could not differentiate the actual amount of water contributing from each aquifer. Therefore, the estimated withdrawal data for these well fields may be in error.

\section{Potentiometric Surfaces Simulated due \\ to Future stress}

Simulated potentiometric surfaces beyond the calibration period require that future stresses be used in the model. The same recharge rates used during the calibration period were used for the projection period. Projected head values had to be specified for both the southwestern boundary of the Farrington aquifer and the Old Bridge aquifer. In both cases, the projected. heads were determined from a linear extension of the values used during the 1959-73 period. It should be noted that the linear head projections for the old Bridge aquifer are estimates. Reductions or additional increases in withdrawals from the old Bridge that may occur in the future will give a different head distribution for the Old Bridge. This may affect the future head distribution in the Farrington. 


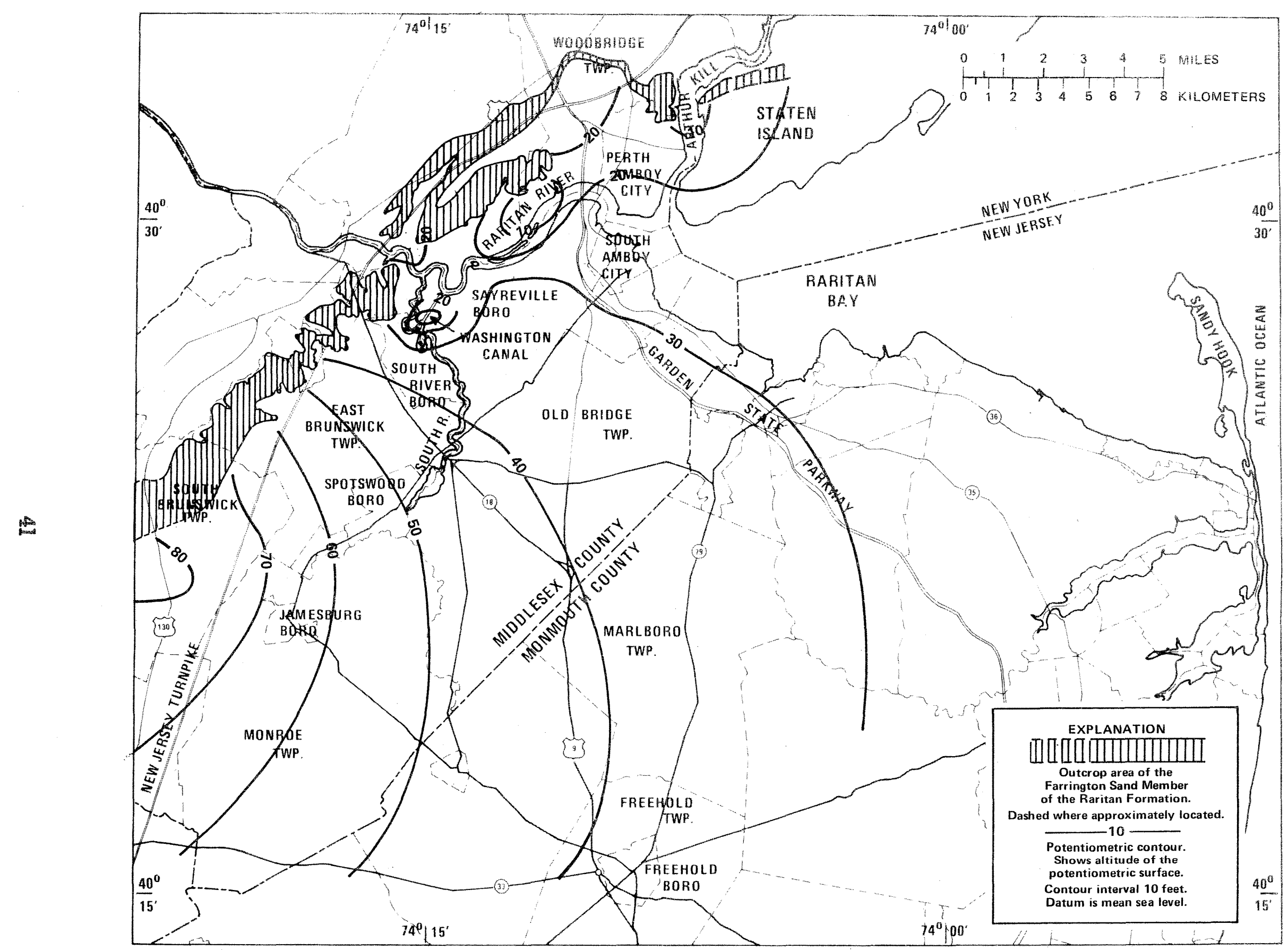

Figure 18. Simulated prepumping (1900) potentiometric surface of the Farrington aquifer. 
Withdrawal rates from the Farrington aquifer were estimated for the period 1974-2000 by using a linear projection of withdrawals from 1959 to 1973. The projection at each pumping node was based on a least squares fit of the average withdrawal rate for each 3-year period from 1959 to 1973. For several nodes, withdrawals occurred during only one or two 3-year periods. The average percent increase for all Farrington withdrawals was used to estimate future withdrawal rates for these nodes.

The projected pumping rates for 1985 and 2000 are shown in figure 19. The total projected withdrawal rate for 1985 is 39.5 $\mathrm{Mgal} / \mathrm{d}\left(61.2 \mathrm{ft}^{3} / \mathrm{s}\right), 53$ percent or a $13.7 \mathrm{Mgal} / \mathrm{d}\left(21.3 \mathrm{ft}^{3} / \mathrm{s}\right)$ increase over the 1973 rate. In a $14 \mathrm{mi}^{2}$ area near Old Bridge, seven nodes have a total projected withdrawal rate of $14.5 \mathrm{Mgal} / \mathrm{d}$ $\left(22.5 \mathrm{ft}^{3} / \mathrm{s}\right)$ for 1985,37 percent over the 1973 withdrawal.

For 2000, the projected total withdrawal is $56.9 \mathrm{Mgal} / \mathrm{d}(88.1$ $\left.\mathrm{ft}^{3} / \mathrm{s}\right)$, a $31.1 \mathrm{Mgal} / \mathrm{d}\left(48.2 \mathrm{ft}^{3} / \mathrm{s}\right)$ or 121 percent increase over the 1973 rate. In the $14 \mathrm{mi}^{2}$ area near Old Bridge, the projected withdrawal is $19.6 \mathrm{Mgal} / \mathrm{d}\left(30.3 \mathrm{ft}^{3} / \mathrm{s}\right), 34$ percent of the total rate for 2000. It also represents an 85 percent increase over the 1973 withdrawal.

The simulated potentiometric surfaces for 1985 and 2000 are shown in figures 20 and 21 , respectively. Their general shapes are similar to that of November 1973, but in each case the cone of depression near Sayreville has increased in depth and in areal extent. By 1985, the potentiometric head near Sayreville will be in excess of 100 ft below mean sea level. By 2000, it will be at least $150 \mathrm{ft}$ below mean sea level.

The increase in size of the cone of depression is illustrated by the cross sections shown in figure 16. The slope of the potentiometric surface between the outcrop area and the center of the cone increases from $8 \mathrm{ft} / \mathrm{mi}$ in 1959 to $18 \mathrm{ft} / \mathrm{mi}$ in 1973. In 1985 and 2000, the projected slope in that area increases to 26 $\mathrm{ft} / \mathrm{mi}$ and $44 \mathrm{ft} / \mathrm{mi}$, respectively. Figure 16 indicates that the siinulated water levels near the outcrop for the year 2000 are below the top of the aquifer and, therefore, dewatering that part of the aquifer near the outcrop.

Figures 22 and 23 show the simulated head declines occurring between 1974-85 and between 1974-2000, respectively. The greatest declines occur near Sayreville with significant declines appearing in Monnouth County. Figure 22 indicates that the potentiometric surface for a large area in Middlesex and Monmouth Counties would be lowered by more than 30 ft from 1974 to 1985 based on projected withdrawal rates. Figure 23 shows that by 2000 , a large area would experience a drop in head of $65 \mathrm{ft}$ with a maximum of $90 \mathrm{ft}$ near pumping areas.

By 1991, the simulated head in the East Brunswick Township Water Department well fields will reach the bottom of the Farrington aquifer at certain areas. Consequently, projected 


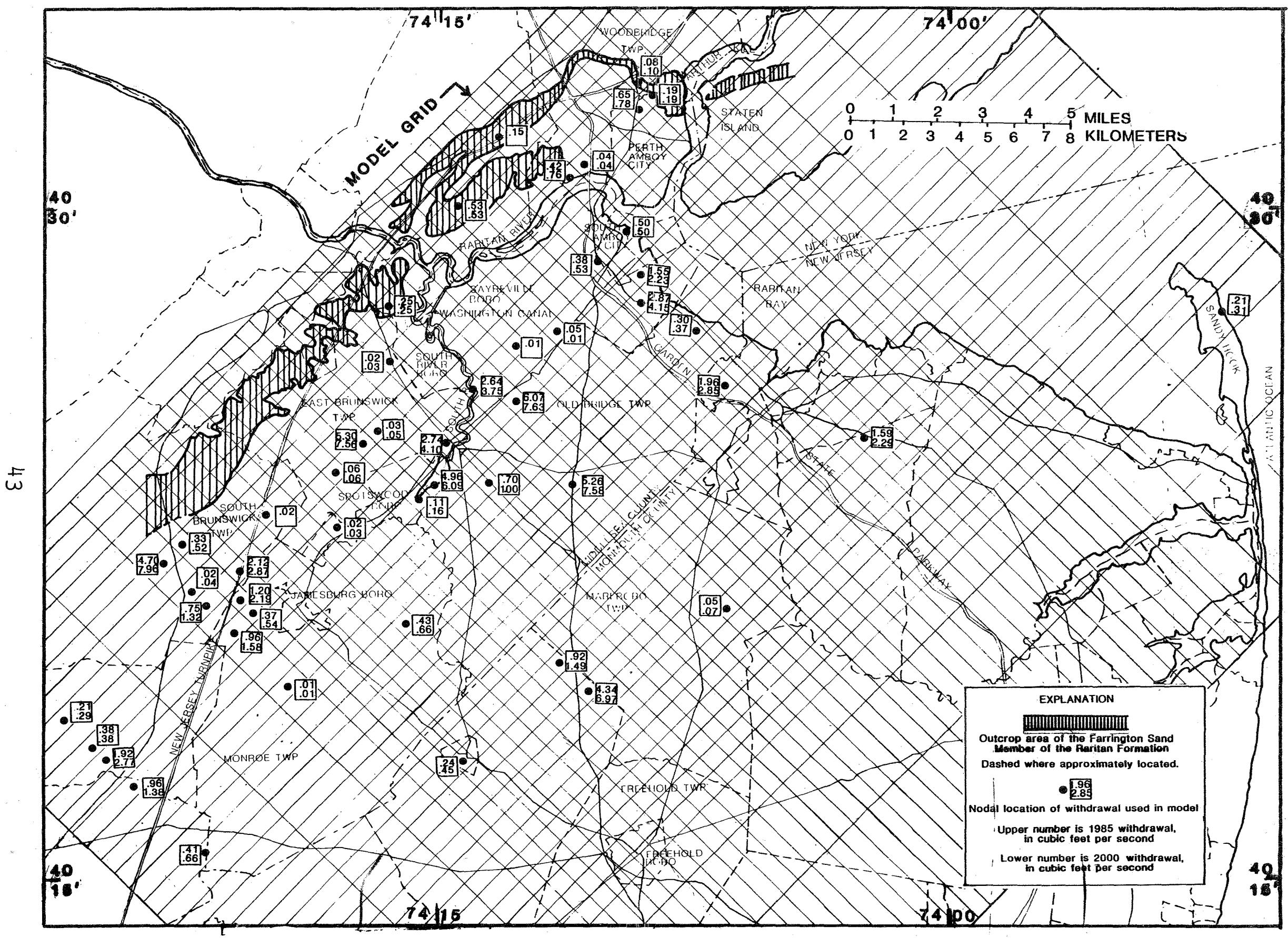

Figure 19.--Dietribution of estimated withdrawals from the Farrington dquifer, 1985-2000. 


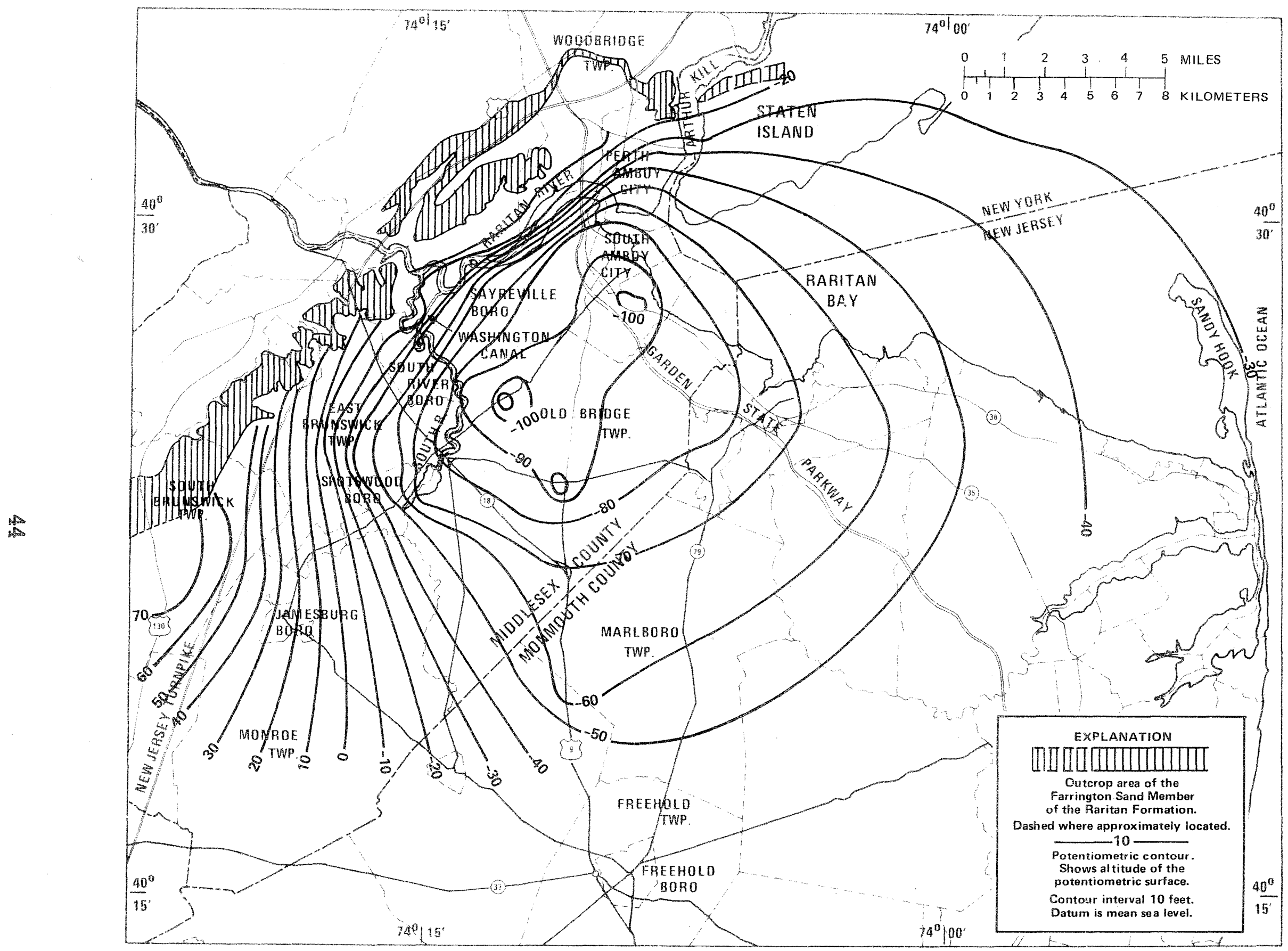

Figure 20. Simulated potentiometric surface of the Farrington aquifer, 1985. 


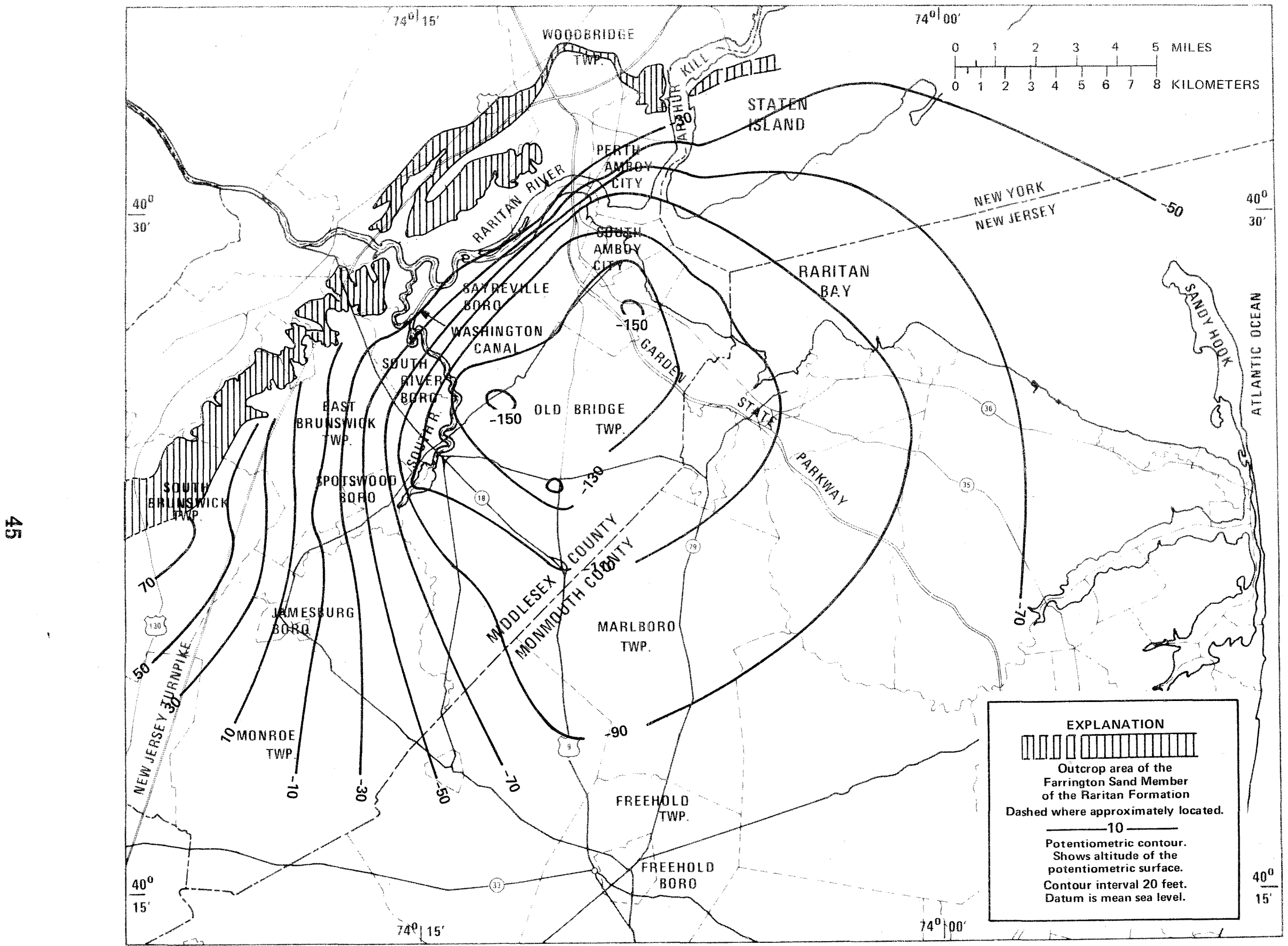

Figure 21. Simulated potentiometric surface of the Farrington aquifer, 2000. 


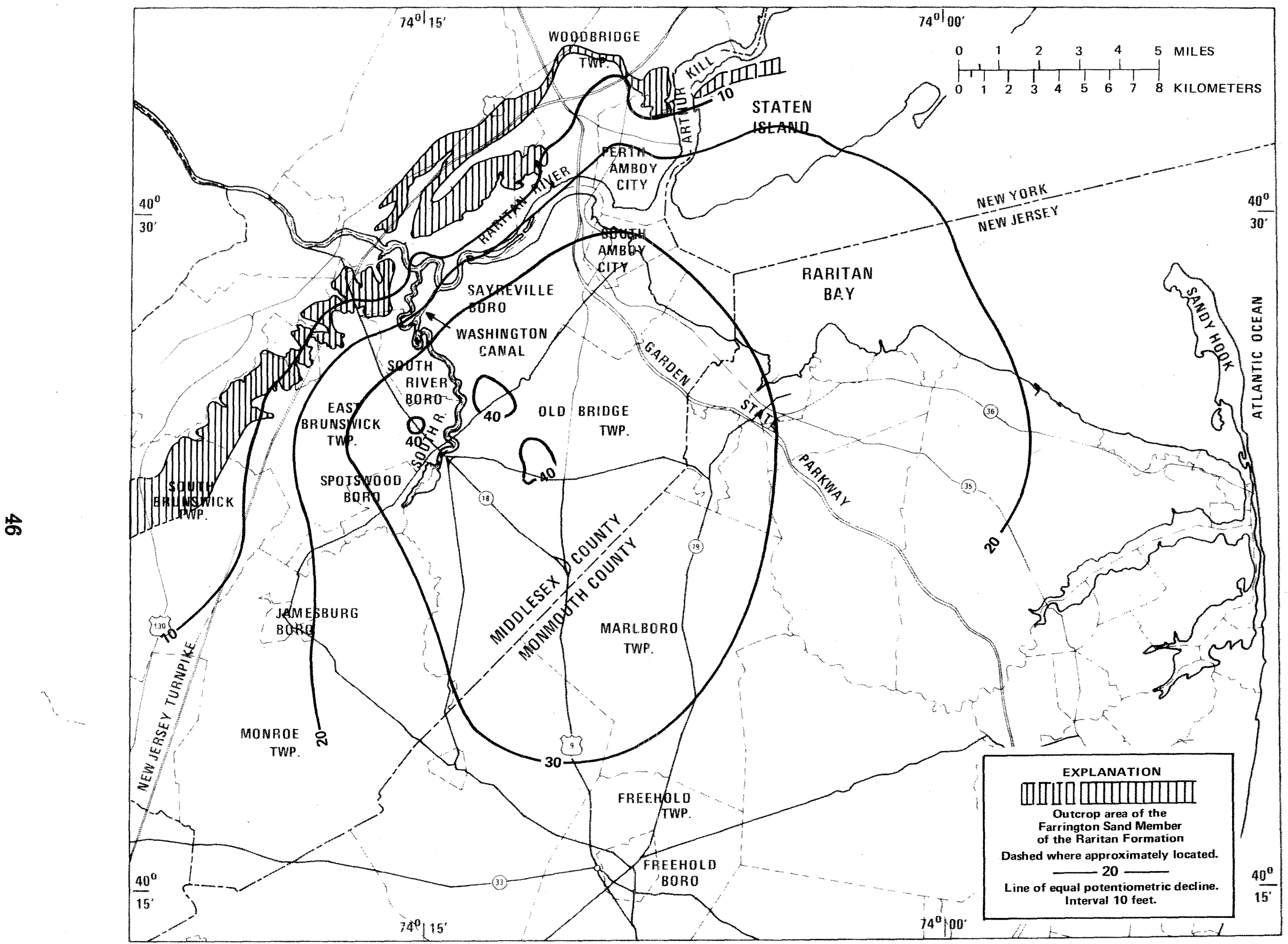

Figure 22. Decline of the simulated potentiometric surface of the Farrington aquifer, 1973-85. 


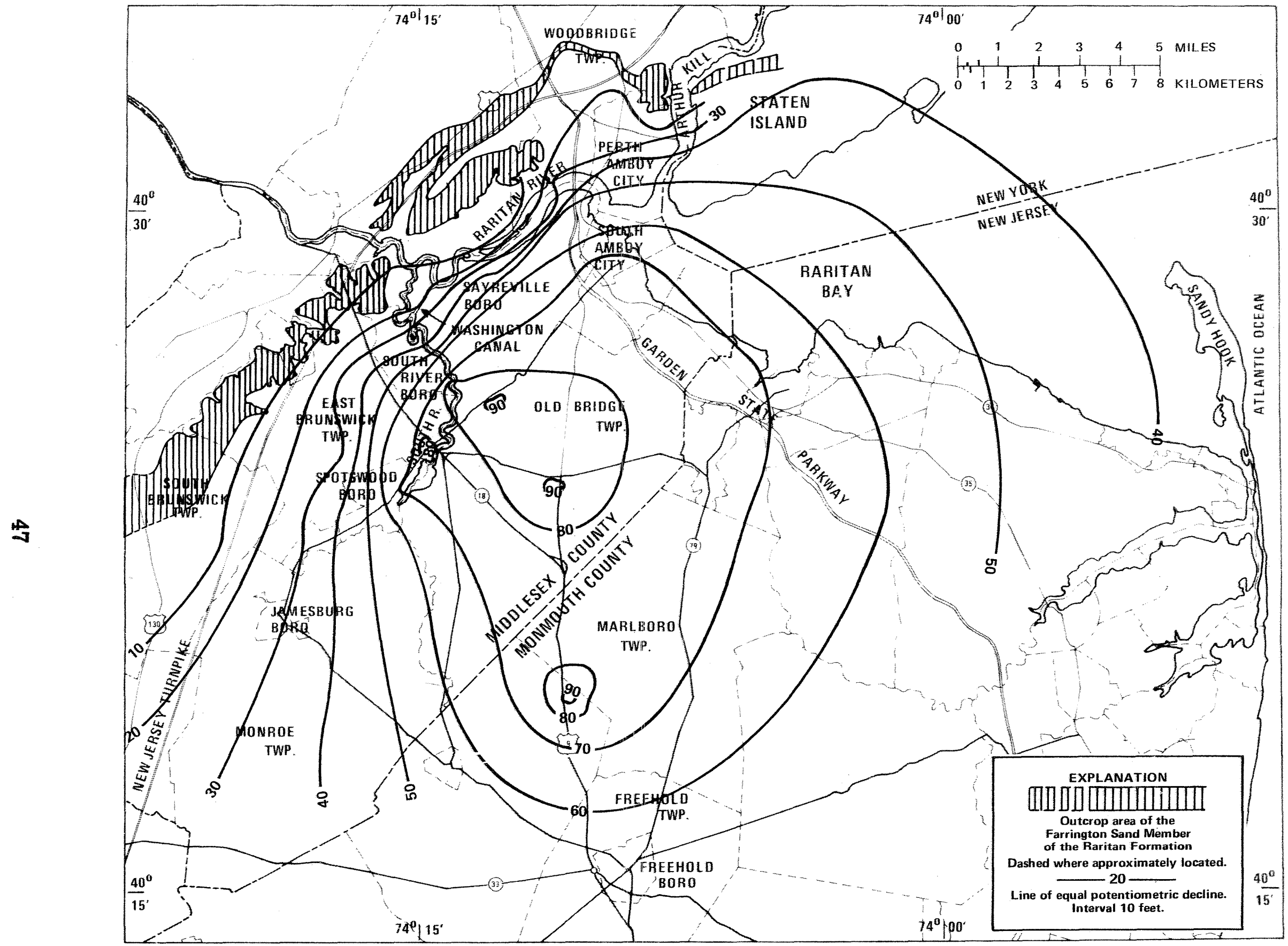

Figure 23. Decline of the simulated potentiometric surface of the Farrington aquifer, 1973-2^00. 
withdrawal rates for the East Brunswick Township Water Department are excluded from the analysis for the period 1995-2000.

The head values specified for the southwestern boundary for the period after 1973 are estimates. Several simulation runs were made to test the effect of different southwestern boundary conditions and the results of the runs compared with the potentiometric surfaces shown in figures 20 and 21. The boundary conditions tested were the following: (1) no flow; (2) specified heads for 1974-2000 equal to 1973 heads; (3) specified heads increased linearly to reach the prepumping levels by year 2000; and (4) specified heads for 1974-2000 at twice the decline rate used for calibration period (1959-73). In all four oases the differences in head by year 2000 ranged from $0 \mathrm{ft}$ in the northwestern to $10 \mathrm{ft}$ in the southeastern parts of the fine-grid area of Middlesex county. An additional run was made whereby the heads for 19742000 were calculated at four times the decline rate used in the calibration period. The difference in head ranged from 0 to. 26 ft in the fine-grid area of Middlesex County. Therefore, specified decline rates for the southwestern boundary greater than two times the rate used for the calibration period will give significantly larger head declines in the fine-grid area than shown in figure 23.

Simulations with large diversions placed near the southwestern boundary during the projection period will not give reliable results. Calculated heads near this boundary are dominated by nodes with specified heads.

\section{Water Budget}

The model was used to make an analysis of the ground-water budget for the entire area as well as for several rectangular subareas. Trescott's (1973) model was modified to permit the calculation of a mass balance of inflow and outflow for a rectangular subarea. The program code was also modified to allow the determination of the amount of vertical leakage into and out of the Farrington aquifer. Ground-water budget analyses were made both for steady-state and transient conditions.

The ground-water budget analysis for steady-state condition prior to significant ground-water withdrawal indicates that the total flow into the Farrington aquifer was $16 \mathrm{ft}^{3} / \mathrm{s}$. Recharge in the outcrop area and vertical leakage from the overlying old Bridge aquifer was $8 \mathrm{ft}^{3} / \mathrm{s}$ each. The budget analysis also indicates that approximately 75 percent of the discharge from the study area occurred in or near the outcrop. This concurs with the statement of Barksdale and others (1958, p. 128) that discharge occurred mainly in and near the outcrop prior to the beginning of withdrawals. The three main areas of discharge determined from the steady-state analysis were: (1) into the Raritan River, Washington Canal, and Arthur Kill; (2) into the southwestern boundary near the outcrop representing flow into the Delaware River south of Trenton; and (3) vertically upward into the 0ld 
Bridge aquifer near the outcrop. discharge occurred southeast of upward into the Old Bridge and as lateral flow into Ocean and Burlington Counties.

Barksdale and others (1958, p. 128-129) estimated that the total flow in the entire thickness of the Potomac-Raritan-Magothy aquifer system was $10 \mathrm{Mgal} / \mathrm{d}\left(6.5 \mathrm{ft}^{3} / \mathrm{s}\right)$ for a 25 -mile long section northeast of Trenton. This value was determined by assuming a total thickness of the aquifer system, an average hydraulic conductivity, and an average hydraulic gradient. The thickness of the Farrington is about 40 to 50 percent of the entire thickness of the Potomac-Raritan-Magothy aquifer system used in the analysis by Barksdale and others (1958, p. 128). Therefore, the average rate of flow in the Farrington aquifer in the 25-mile section northeast of Trenton would be about $3 \mathrm{ft}^{3} / \mathrm{s}$, if the same values for hydraulic conductivity and hydraulic gradient used by Barksdale and others (1958, p. 128) were applied. The model calculated the rate of flow for this cross-sectional area to be $2.4 \mathrm{ft}^{3} / \mathrm{s}$, indicating the model concurred with Barksdale and others: (1958) estimate.

Water-budget analysis for the entire area for transient conditions (1959-2000) indicates the importance of vertical leakage from the 01d Bridge as a source of recharge into the Farrington aquifer. Vertical leakage is especially significant in the vicinity of South. Brunswick Township. Over 60 percent of the total vertical leakage into the Farrington aquifer occurs in or near this area.

- Other sources of water to the Farrington aquifer indicated by the analysis for transient conditions include recharge (precipitation) in the outcrop area, water released from storage, and infiltration from the Washington Canal and segments of the Raritan River. It is apparent that prior to development the hydraulic gradient was toward the Raritan River and the Washington Canal area. However, due to withdrawals, this gradient was reversed sometime before 1959. Water-budget analyses show that infiltration from these two surface-water bodies increased with time during the simulation period.

A water-budget analysis for transient conditions was also made for a subarea located primarily in Middlesex County. This subarea consists of an area enconpassed by rows 2 to 21 and colurnns 9 to 43 (see fig. 12). Lateral flow into each side of this rectangular subarea during each time step was deterinined by Darcy's Law. Lateral inflow for the last time step of 1973 was $14.3 \mathrm{ft} / \mathrm{s}$, or about 48 percent of the total inflow to the subarea. Approximately 75 percent of the lateral flow entered the subarea through its southwest side. Part of the source of this lateral inflow was vertical leakage (mainly from the Old Bridge) outside of this subarea. The lateral flow moved toward the cone of depression in Sayreville. Other sources of 'water for the subarea included direct recharge $\left(5.4 \mathrm{ft}^{3} / \mathrm{s}\right)$, vertical leakage 
(4.3 $\left.\mathrm{ft}^{3} / \mathrm{s}\right)$, infiltration from surface-water bodies $\left(2.6 \mathrm{ft}^{3} / \mathrm{s}\right.$, and water released from storage $\left(3 . \mathrm{ft}^{3} / \mathrm{s}\right)$. All of these occurred within the subarea.

Discharge from the subarea for the last time step of 1973 was largely by withdrawals through wells. The total withdrawal rate through wells was $26.5 \mathrm{ft}^{3} / \mathrm{s}$. Combined discharge through vertical leakage to the old Bridge and to surface-water bodies was approximately $3.2 \mathrm{ft}^{3} / \mathrm{s}$. The difference between inflow, water released from storage, and outflow is $0.3 \mathrm{ft}^{3} / \mathrm{s}$, about 1 percent of outflow, which is probably due to calculation errors inherent in the computer.

A budget analysis of the subarea under transient conditions for the year 2000 produced a similar percentage of inflows and discharges. However, the values were greater than those calculated for 1973 .

\section{SUMMARY AND CONCLUSIONS}

The Potomac-Raritan-Magothy aquifer system consisting of sand, silt, clay, and gravel of cretaceous age is the most productive source of ground water in the northern part of the New Jersey Coastal Plain. The Farrington and the Old Bridge aquifers are the two major aquifers within the Potomac-Raritan-Magothy system in Middlesex and Monmouth Counties.

The Farrington aquifer consists primarily of the Farrington Sand Member of the Raritan Formation and overlying surficial deposits in Middlesex County. In Monmouth County, the aquifer consists of the underlying sand unit of the Potomac Group. The aquifer ranges in thickness from a featheredge at its outcrop to more than $170 \mathrm{ft}$ in Marlboro Township, Monmouth County. The mean specific capacity of 99 wells, mostly in Middlesex County, is 20.4 (gal/min)/ft of drawdown. The mean specific capacity per ft of well screen is 0.62 (gal/min)/ft per foot of screen.

Overlying the Farrington Sand Member is a confining unit of silt and clay composed mainly of the Woodbridge Clay Member of the Raritan Formation. The confining unit has a maximum thickness of 244 ft and separates the overlying old Bridge aquifer from the Farrington aquifer.

A major cone of depression existed in the Farrington aquifer near Sayreville in 1959 and 1973. Cones of depression for the Old Bridge aquifer occurred in the Keyport area in 1959 and 1973 and in the Freehold area in 1973. Withdrawals from wells tapping the Farrington aquifer increased from $12.1 \mathrm{Mgal} / \mathrm{d}\left(18.7 \mathrm{ft}^{3} / \mathrm{s}\right)$ in 1959 to 25.8 $\mathrm{Mgal} / \mathrm{d}\left(39.9 \mathrm{ft}^{3} / \mathrm{s}\right)$ in 1973. The major recharge area for both the Farrington aquifer and the old Bridge aquifer is in South Brunswick Township in Middlesex County.

A finite-difference digital-flow model was developed to simulate water-table and artesian conditions in the Farrington 
aquifer. A lateral hydraulic conductivity of $105 \mathrm{ft} / \mathrm{d}$ was used for most of the area. A uniform storage coefficient of $1.6 \times 10^{-4}$ was used for artesian conditions and a uniform specific yield of 0.25 for water-table conditions. Vertical hydraulic conductivity of the upper confining unit ranged from $4.2 \times 10^{-7}$ to $1.0 \times 10^{-10}$ $\mathrm{ft} / \mathrm{s}$ and a specific storage of $4 \times 10^{-5} \mathrm{ft}^{-1}$ was used. The model includes the effects of declining water levels in the Old Bridge aquifer. For transient conditions, the 1959 Farrington potentiometric surface was used as the starting head and the 1959 Old Bridge potentiometric surface was used as the initial head overlying the confining unit. Old Bridge heads were adjusted at each node and at every time step using the average rate of change in head for each node between 1959 and 1973.

The model was calibrated for the 15-year period, 1959-73. Yearly withdrawal rates were used to stress the aquifer. Calibration of the model was achieved by comparing the calculated potentiometric surface for the end of the 15-year period with the observed November 1973 potentiometric surface. In addition, hydrographs of selected wells were compared with model results. After calibration, steady-state conditions were simulated. The model results compared favorably with available prepumping water levels.

The potentiometric surface of the Farrington aquifer was simulated to the year 2000 by using projected withdrawals. The withdrawals were estimated by a linear projection determined from 1959-73 withdrawals. The simulated potentiometric surface for the Sayreville area is in excess of $100 \mathrm{ft}$ below mean sea level by 1985 and exceeds $150 \mathrm{ft}$ by 2000 . The simulated potentiometric surfaces for 1985 and 2000 are somewhat similar to the 1973 surface, but the cone of depression in the vicinity of Sayreville is greater in depth and area.

A ground-water budget analysis for steady-state conditions prior to development indicates that total inflow into the Farrington aquifer was $16 \mathrm{ft}^{3} / \mathrm{s}$. Recharge in the outcrop area and vertical leakage from the old Bridge each accounted for about 8 $\mathrm{ft}^{3} / \mathrm{s}$ each. Approximately 75 percent of the discharge occurred in or near the outcrop area. Most of this discharge was into the Raritan River, Washington Canal area, and Arthur Kill. The remaining 25 percent of the discharge occurred southeast of the outcrop as vertical leakage into the overlying old Bridge aquifer and as lateral flow into Ocean and Burlington Counties.

The budget analysis for transient conditions (1959-2000) indicates the importance of vertical leakage (mainly from the old Bridge) as a source of water to the Farrington aquifer. Other sources of water include recharge in the outcrop area, water released from storage, and infiltration from the washington Canal and part of the Raritan River. The original hydraulic gradient toward the two surface-water bodies was reversed prior to 1959, thus causing the Washington Canal and part of the Raritan River to recharge the aquifer. The budget analysis also shows that 
recharge into the aquifer from these two surfacewater bodies increased with time during the simulation.

A transient budget analysis for the last time step of 1973 was made for a subarea consisting mainly of Middlesex County. About 48 percent $\left(14.3 \mathrm{ft}^{3} / \mathrm{s}\right)$ of the total inflow to the subarea was through its boundaries. Other sources included direct recharge $\left(5.4 \mathrm{ft}^{3} / \mathrm{s}\right)$, vertical leakage, mainly from the 0ld Bridge, ( $\left.2.6 \mathrm{ft}^{3} / \mathrm{s}\right)$, and water released from storage $\left(3.4 \mathrm{ft}^{3} / \mathrm{s}\right)$. Withdrawals from wells $\left(26.5 \mathrm{ft}^{3} / \mathrm{s}\right)$ were the major discharge from the subarea of the aquifer. The combined rate of discharge through vertical leakage to the old Bridge and to surfacewater bodies was approximately $3.2 \mathrm{ft}^{3} / \mathrm{s}$.

Analysis for the year 2000 showed a similar percentage. However, the values were greater than those calculated for 1973 . 
Anderson, H. R., and Appel, C. A., 1969, Geology and ground-water resources of Ocean County, New Jersey: New Jersey Department of Conservation and Economic Development, Division of Water Policy and Supply Special Report 29, $93 \mathrm{p}$.

Appel, C. A., 1962, Salt-water encroachment into aquifers of the Raritan Formation in the Sayreville area, Middlesex Councy, New Jersey: New Jersey Department of Conservation and Economic Development, Division of Water Policy and Supply Special Report $17,47 \mathrm{p}$.

Barksdale, H. C., 1937, water supplies from the No. 1 Sand in the vicinity of Parlin, New Jersey: New Jersey Water Policy Commission Special Report 7, $33 \mathrm{p}$.

Barksdale, H. C., Greeman, D. W., Lang, S. M., Hilton, G. S., and Outlaw, D. E., 1958, Ground-water resources in the tri-state region adjacent to the lower Delaware River: New Jersey Department of Conservation and Economic Development, Division of Water Policy and Supply Special Report 13, $190 \mathrm{p}$.

Barksdale, H. C., Johnson, M. E., Baker, R. C., Schaefer, E. J., and DeBuchananne, G. D., 1943, The ground-water supplies of Middlesex County, New Jersey: New Jersey Water Policy Com mission Special Report 8, $160 \mathrm{p}$.

Bennett, G. D., 1976, Electric analog simulation of the aquifers along the South Coast of Puerto Rico: U.S. Geological Survey Open-File Report 76-4, $101 \mathrm{p}$.

Bredehoeft, J. D., and Pinder, G. J., 1970, Digital analysis of areal flow in multiaquifer ground-water systems: A quasi three-dimensional model: Water Resources Research, $v .6$, no. 3, p. 883-888.

Doyle, J. A., 1969, Cretaceous angiosperm pollen of the Atlantic Coastal Plain and its evolutionary significance: Journal Arnold Arboretum v. 50, no. 1, $35 \mathrm{p}$.

Farlekas, G. M., Nemickas, Bronius, and Gill, H. E., 1976, Geology and ground-water resources of Camden County, New Jersey: U.S. Geological Survey Water-Resources Investigations 76-76, $146 \mathrm{p}$.

Gill, H. E., and Farlekas, G. M., 1976, Geohydrologic maps of the Potomac-Raritan-Magothy aquifer system in the New Jersey Coastal Plain: U.S. Geological Survey Hydrologic Investigations Atlas HA-557.

Hantush, M. S., 1960, Modification of the theory of leaky aquifers: Journal of Geophysical Research, v. 65, no. 11, p. 3713-3725.

Hardt, W. F., and Jablonski, L. A., 1959, Results of a pumping test in the vicinity of Woodbridge, Middlesex County, New Jersey: U.S. Geological Survey Open-File Report, 8 p.

Hasan, Asghar, Kasabach, H. F., and Malone, J. E., 1969, Water Resources of the Sayreville area Middlesex County, New Jersey: New Jersey Department of Conservation and Economic Development, Division of Water Policy and Supply water $R$ e sources Circular $20,32 \mathrm{p}$.

Jablonski, L. A., 1968, Ground-water resources of Monmouth County, New Jersey: New Jersey Department of Conservation and 
Economic Development, Division of Water Policy and Supply Special Report 23, $117 \mathrm{p}$.

Kimmel, G. E., 1973, Change in potentiometric head in the Lloyd aquifer, Long Island, New York: U.S. Geological Survey Journal of Research, v. 1, p. 345-350.

Leggette, Brashears, and Graham consulting ground-water geologists, 1961, Ground-water conditions in South Brunswick Township, New Jersey: New York City, 26 p.

Lohman, S. W., 1972, Ground-water hydraulics: U.S. Geological Survey Professional Paper $708,70 \mathrm{p}$.

Lohman, S. W., and others, 1972, Definitions of selected groundwater terms--revisions and conceptual refinements: U.S. Geological Survey Water-Supply Paper 1988, 21 p.

Mattick, R. E., Perry, W. J., Jr., Robbins, E., Rhodehamel, E. C., Weed, E. G. A., Taylor, H. L., Krivoy, H. L., and Bayer, K. C., 1975, Sediments, structural framework, petroleum potential, environmental conditions, and operational considerations of the United States Mid-Atlantic Outer Continental Shelf: U.S. Geological Survey Open-File Report 75-61, 143 p.

Owens, J. P., and Minard, J. P., 1975, Geologic Map of the Surficial Deposits in the Trenton area, New Jersey and PennsyIvania, U.S. Geological Survey Miscellaneous Geologic Investigations Map I-884.

Owens, J. P., Minard, J. P., and Sohl, N. F., 1968, Cretaceous deltas in the northern New Jersey Coastal Plain, in Finks, R. L., ed., Guidebook to field excursions at the $40 t h$ Annual Meeting of the New York State Geological Associations: New York, Queens College of the City University, p. 33-48.

Owens, J. P., and Sohl, N. F., 1969, Shelf and deltaic paleoenvironments in the Cretaceous-Tertiary Formations of the New Jersey Coastal Plain, in Subitzky, Seymour, ed., Geology of the selected areas in New Jersey and eastern Pennsylvania and guidebook of excursions: Geological Society of America and Associated Societies, November 1969, Annual Meeting, Atlantic City, N.J., New Brunswick, N.J., Rutgers University Press, p. $235-278$.

Peaceman, D. W., and Rachford, H. H., Jr., 1955, The numerical solution of parabolic and elliptic differential equations: Society of Industrial and Applied Mathematics Journal, v. 3, no. $1, \mathrm{p} .28-41$.

Perlmutter, N. M., and Arrow, Theodore, 1953, Ground water in Bronx, New York, Richmond Counties with summary data on Kings and Queens Counties, New York City, New York: New York State Department of Conservation, Water Power and Control Commission Bulletin GW-32, $86 \mathrm{p}$.

Perry W. J., Jr., Minard, J. P., Weed, E. G. A., Robbins, E. I., and Rhodehamel, E. C., 1975, Stratigraphy of Atlantic Coastal Margin of United States North of Cape Hatteras-Brief Survey: American Association of. Petroleum Geologists Bulletin, v. $59, \mathrm{p} .1529-1548$.

Pinder, G. F., 1970, A digital model for aquifer evaluation: U.S. Geological Survey Techniques of Water-Resources Investigations, Book 7, Chapter C1, 18 p. [Superseded by Trescott, Pinder, and Larsen, 1976]. 
Pinder, G. F., and Bredehoeft, J. D., 1968, Application of a digital computer for aquifer evaluation: Water Resources Research, v. 4, no. 5, p. 1069-1093.

Rhodehamel, E. C., 1970, A hydrologic analysis of the New Jersey Pine Barrens region: New Jersey Department of Environmental Protection, Division of Water Policy and Supply Water Resources Circular 22, $35 \mathrm{p}$.

, 1973, Geology and water resources of the wharton Tract and the Mullica River basin in southern New Jersey: New Jersey Department of Environmental Protection, Division of Water Resources Special Report 36, $58 \mathrm{p}$.

, 1977, Lithologic descriptions in P. H. Schoelle, ed., Geological studies on the COST No. B-2 Well, U.S. M i d Atlantic Outer Continental Shelf area, 1977: U.S. Geological Survey Circular 750, p. 15-22.

Sirkin, L. A., 1974, Palynology and stratigraphy of Cretaceous strata in Long Island, New York, and Block Island, Rhode Island: U.S. Geological Survey Journal of Research, v. 2, p. $431-440$.

Thiem, Guither, 1906, Hydrologische methoden: Leipzig, J. M., Gebhardt, $56 \mathrm{p}$.

Trescott, P. C., 1973, Iterative digital model for aquifer evaluation: U.S. Geological Survey Open-File Report, 18 p.

Trescott, P. C., Pinder, G. F., and Larson, S. P., 1976, Finitedifference model for aquifer simulation in two dimensions with results of numerical experiments: U.S. Geological Survey Techniques of Water-Resources Investigations, Book 7 , Ghapter C1, $116 \mathrm{p}$.

Vecchioli, John, and Palmer, M. M., 1962, Ground-water resources of Mercer County, N.J.: New Jersey Department of Conservation and Economic Development, Division of Water Policy and Supply Special Report 19, $71 \mathrm{p}$.

Widmer, Kemble, 1965, Geology of the ground-water resources of Mercer County: New Jersey Geology Report, ser. 7, $115 \mathrm{p}$.

Wilson, G. R., van der Leeden, Frits, Stollar, R. L., and Geraghty, J. J., 1972, Water resources of the Upper Milistone River basin, New Jersey: New Jersey Department of Environmental Protection, Division of Water Resources Special Report $35,126 \mathrm{p}$.

Wolfe, J. A., and Pakiser, H. M., 1971, Stratigraphic interpretations of some Cretaceous microfossil floras of the Middle Atlantic States: U.S. Geological Survey Professional Paper $750-B, p \cdot B 35-B 47$. 